\title{
Magnetite-Silica Core/Shell Nanostructures: From Surface Functionalization towards Biomedical Applications-A Review
}

\author{
Angela Spoială ${ }^{1,2} \mathbb{D}$, Cornelia-Ioana Ilie ${ }^{1,2} \mathbb{D}$, Luminița Narcisa Crăciun ${ }^{3}$, Denisa Ficai ${ }^{2,3}, * \mathbb{D}$, Anton Ficai ${ }^{1,2,4} \mathbb{D}$ \\ and Ecaterina Andronescu 1,2,4 (D)
}

check for

updates

Citation: Spoială, A.; Ilie, C.-I.; Crăciun, L.N.; Ficai, D.; Ficai, A.; Andronescu, E. Magnetite-Silica Core/Shell Nanostructures: From Surface Functionalization towards Biomedical Applications-A Review. Appl. Sci. 2021, 11, 11075. https:// doi.org/10.3390/app112211075

Academic Editors: Pietro Calandra and Domenico Lombardo

Received: 11 September 2021

Accepted: 19 November 2021

Published: 22 November 2021

Publisher's Note: MDPI stays neutral with regard to jurisdictional claims in published maps and institutional affiliations.

Copyright: (c) 2021 by the authors. Licensee MDPI, Basel, Switzerland. This article is an open access article distributed under the terms and conditions of the Creative Commons Attribution (CC BY) license (https:/ / creativecommons.org/licenses/by/ $4.0 /)$.
1 Department of Science and Engineering of Oxide Materials and Nanomaterials, Faculty of Applied Chemistry and Materials Science, University Politehnica of Bucharest, 1-7 Gh Polizu Street, 011061 Bucharest, Romania; angela.spoiala83@yahoo.com (A.S.); cornelia.ilie18@gmail.com (C.-I.I.); anton_ficai81@yahoo.com (A.F.); ecaterina.andronescu@upb.ro (E.A.)

2 National Centre for Micro and Nanomaterials and National Centre for Food Safety, Faculty of Applied Chemistry and Materials Science, University Politehnica of Bucharest, Spl. Indendentei 313, 060042 Bucharest, Romania

3 Department of Inorganic Chemistry, Physical Chemistry, and Electrochemistry, Faculty of Applied Chemistry and Materials Science, University Politehnica of Bucharest, 1-7 Gh Polizu Street, 050054 Bucharest, Romania; luminita.craciun71@yahoo.com

4 Academy of Romanian Scientists, 3 Ilfov Street, 050045 Bucharest, Romania

* Correspondence: denisaficai@yahoo.ro

Featured Application: The magnetic core can be used in targeting but also in magnetic actuation while silica can have multiple role: compatibilizing agent, protecting agent even in harsh conditions, drug reservoir or adsorbent, etc. Thus, magnetite-silica core/shell nanostructures can be used in many applications including development of drug delivery systems, contrast agent, specific adsorbent, filler in different polymers, magnetic micro devices, etc.

Abstract: The interconnection of nanotechnology and medicine could lead to improved materials, offering a better quality of life and new opportunities for biomedical applications, moving from research to clinical applications. Magnetite nanoparticles are interesting magnetic nanomaterials because of the property-depending methods chosen for their synthesis. Magnetite nanoparticles can be coated with various materials, resulting in "core/shell" magnetic structures with tunable properties. To synthesize promising materials with promising implications for biomedical applications, the researchers functionalized magnetite nanoparticles with silica and, thanks to the presence of silanol groups, the functionality, biocompatibility, and hydrophilicity were improved. This review highlights the most important synthesis methods for silica-coated with magnetite nanoparticles. From the presented methods, the most used was the Stöber method; there are also other syntheses presented in the review, such as co-precipitation, sol-gel, thermal decomposition, and the hydrothermal method. The second part of the review presents the main applications of magnetite-silica core/shell nanostructures. Magnetite-silica core/shell nanostructures have promising biomedical applications in magnetic resonance imaging (MRI) as a contrast agent, hyperthermia, drug delivery systems, and selective cancer therapy but also in developing magnetic micro devices.

Keywords: magnetite-silica; core/shell nanostructures; biomedical application

\section{Introduction}

Nanotechnology and nanoscience involve the ability to manipulate matter with at least a dimension between 1 and 100 nanometers being related to imaging, measure, and model, but also to the improvement of materials and applications by exploring their unique properties exposed at the nanometric scale [1].

Over the past decade, nanotechnology has been integrated into medicine and biology by developing a new active and significant research area, nanomedicine, which 
was materialized in clinical applications such as diagnosis and therapy, having many perspectives to broaden these applications and to extend them from lab to clinic [2,3]. In this new area of interest, nanobiotechnology approaches have been used in developing core/shell nanostructures of different functionalities. The most common materials used for biomedical applications were superparamagnetic nanoparticles and, especially, magnetite nanoparticles because of their unique properties that will be explained in this review [4].

Nanotechnology offers nano dimensioned materials such as nanoparticles, nanotubes, nanowires, thin films, and nanocomposites functionalized or coated on a specific surface to obtain different nanomaterials that can be useful in many applications [4,5]. As drug delivery platforms, nanoparticles would be able to load bio-therapeutic agents and dissolve in any environment with great potential in biomedical applications, such as cancer diagnosis and therapy $[1,4,5]$. For in vivo applications of nanoparticles, certain properties need to be considered, such as surface morphology, chemistry, and molecular weight. Depending on the materials used and the structure of the materials in the nanoparticles, we classify them into distinct groups, such as polymeric nanoparticles, lipid nanoparticles, liposomes, polymeric micelles, quantum dots, dendrimers, metallic nanoparticles, carbonaceous materials, core/shell nanoparticles, and others [6].

Nanotechnology is one of the most important areas of research worldwide [7-23]. Using nanotechnology in various research sectors, significant improvements were recorded, with some of these sectors including information, medicine, energy, environmental science, and transport. Nanomaterials and nanoparticles have contributed to the development of modern computing and electronics such as transistors, memory chips, and semiconductors $[22,23]$. Through nanotechnology in medicine, researchers have designed and developed nanoparticles and nanomaterials for the prevention, diagnosis, and treatment of different diseases $[7,8]$. Researchers have incorporated nanotechnology into solar panels and batteries, and have developed many new, efficient, and renewable energy sources [18-20]. Engineers have manufactured nanomaterial membranes that clean the contaminants from wastewater [21]. The nanoengineering materials used in the automotive industry have provided innovative solutions to improve transportation infrastructure [24].

The next section will present significant information regarding the most studied nanoparticles for biomedical applications. Magnetite nanoparticles are interesting magnetic nanomaterials, considered a challenge for modern scientific research because of their oxidative sensitivity to other magnetic mixtures; "superparamagnetics" are particles that are guided with the help of an external magnetic field, and they can be magnetically stirred to the desired tumor/place. Magnetite particles have significant properties depending on the synthesis methods $[4,5,25]$.

Magnetite nanoparticles are used in multiple applications, particularly in biomedicine, because of the magnetic field, the fact that they can carry specific drugs, and that they can support specific receptors to ensure targeting of various tissues, organs, or even cells [26]. Magnetite nanoparticles are also widely used in environmental applications because they can easily be removed from the environment. These magnetite nanomaterials are used as absorbents, and also as photocatalysts to degrade various agents, including organic pollutants, antibiotics, and pesticides [27-31]. To avoid agglomeration and improve the stabilization of magnetite nanoparticles in the target tissue, they are generally covered with a coating shell $[4,32]$.

Another great applicability of magnetic iron oxide nanoparticles is in superparamagnetic iron oxide nanoparticles (SPIONs), which have attracted attention due to their properties for loading biological active agents with multiple purposes in biological applications. For this reason, it has been shown that superparamagnetic iron oxide nanoparticles (SPIONs) coated with silica presented potential in biomedical applications such as imaging, contrast agents, and drug targeted therapy [33].

Guo et al. [34] demonstrated a facile, low-cost synthesis for the fabrication of a different type of magnetite such as monodisperse superparamagnetic single-crystal magnetite 
nanoparticles with a mesoporous structure (MSSMN) through a very simple solvothermal method with promising applications in drug delivery.

In the context of surface functionalization, surface characteristics are aspects that should be considered when applying nanoparticles in biomedical applications. The size of nanoparticles and the surface ratio of atoms in a nanoparticle are critical issues when it comes to magnetization. Thus, the nanoparticles and their oxides have a ferromagnetic effect. For a better understanding of the characteristics of ferromagnetism, it has been brought to our attention that non-magnetic nanoparticles such as cerium oxide and aluminium oxide present magnetic hysteresis at room temperature, and materials such as niobium nitride have ferromagnetic properties. Since nanoparticles are small, the higher the ferromagnetic function is [15]. The sum of magnetization of a nanoparticle consists of two effects: one that occurs on the surface and the second inside the particle core. According to this research, the existence of superficial defects has promoted a magnetic disturbance that continues within the closest layer. The most prominent characteristic of magnetic nanoparticles to be understood is the superficial effect and anisotropy; therefore, their understanding is primordial in the development of magnetic nanoparticles with applications in biomedicine, such as MRI and magnetic hyperthermia [15,35].

Through the surface functionalization of magnetite nanoparticles, researchers achieve unique and significant improvements in their properties, especially stability $[36,37]$. The silica coating can be one of the best options for surface functionalization because of its greater stability against degradation compared to most organic shells. The test results suggested that functionalized silica exhibited improved properties compared to before functionalization. The immobilization of biological agents such as enzymes and drugs onto the porous structure of silica was conducted in developing better stability of the nanostructure [38]. Silica has groups of silanol on the surface and their presence improves the capacity for functionalization, biocompatibility, and hydrophilic-hydrophobic ratio, making them excellent materials for different biomedical [39-41] and environmental applications [42]. Hui et al. [43] used the Stöber method to coat silica on magnetite nanoparticles during trials, and Roca et al. [44] used the sol-gel method to coat silica on maghemite nanosphere. The literature provides many studies involving micro-emulsion and reverses micro-emulsion that describe the coating methods for iron oxide with silica. These synthesis methods offer significant advantages in obtaining preferential nanoparticles and have significant implications for biomedical applications. The major challenge for researchers was to integrate the structure of cubic magnetic nanoparticles into the structure of magnetite and functionalize it with silica for developing a rising material for biomedical applications. Through this study, a facile and novel development of the tunable silica thickness and enhancement in stability and biocompatibility of the $\mathrm{Fe}_{3} \mathrm{O}_{4} / \mathrm{SiO}_{2}$ core/shell nanocubes was demonstrated. These materials presented excellent magnetization and an affinity for binding molecules of the formed core/shell, which make them promising materials for diverse bio-sensing applications $[45,46]$. Many types of research illustrate the use of magnets in different special applications, for example, the removal of different metallic parts such as safety pins $[47,48]$, bullets, grenade splinters, dental prostheses, and catheters navigating through the brain and body [35,49].

Recently, magnetic nanoparticles have been intensively used in magnetic guide applications, bioaccumulation, and hyperthermia, especially because of their magnetic properties and their interaction with external electromagnetic fields. Magnetite nanoparticles are interesting because of the two valence states of the iron cations, $\mathrm{Fe}^{2+}$ and $\mathrm{Fe}^{3+}$, that have inverse spinel structures with a special surface modification capacity. This also includes the possibility to be coated and to manufacture core/shell systems only by maintaining the superparamagnetic properties of the core [50-52].

Magnetite nanoparticles have gained interest in applications from biomedical fields, such as drug delivery $[53,54]$ and therapeutic treatments $[55,56]$, as well as contrast agents for MRI [54], magneto-thermal therapy [57], enzyme immobilization [58,59], bioseparation $[54,55]$, cells labelling $[60,61]$, hyperthermia $[53,54]$, and tissue engineering $[54,55]$. 
Recently, studies have demonstrated that biomedicine uses coated magnetic nanoparticles to improve their stability and biocompatibility. Researchers have seen excellent materials such as silica that were considered as shells for magnetic nanoparticles, because they had protective behavior and adapted to various chemicals and molecules. The most common method used for the functionalization of silica on the surface of magnetite nanoparticles is the Stöber sol-gel method $[5,50,51,62,63]$.

The Stöber sol-gel method is a chemical synthesis usually used to prepare silica nanoparticles with controllable growth and uniform size particles for diverse applications. Since it was discovered, the Stöber method remains the most widely used wet chemistry synthesis approach to synthesize silica nanoparticles. Through the Stöber sol-gel method, researchers were able to produce large silica particles with diameters ranging from 50-2000 nm, depending on conditions. Researchers were able to understand their kinetics and mechanisms, and more control over particle size, distribution, and tunable physical properties were also achieved $[64,65]$. Typically, in the Stöber method, ethanol and ammonia (catalyst) are mixed with a small amount of deionized water, followed by the addition of tetraethylorthosilicate (TEOS) under continuous stirring, which can be replaced by sonication. In this method, the rate-determining steps which can affect the physicochemical properties of silica nanoparticles are a concentration of TEOS, ammonia, water, type and amount of solvent, reaction temperature, and $\mathrm{pH}$ [6].

The major advantage of the Stöber method is that it can synthesize almost monodisperse silica nanoparticles and, as already said before, it remains the most widely used wet chemistry synthesis approach for silica nanoparticles. Because monodisperse silica nanoparticles with controlled sizes are produced, the process is considered a convenient approach in preparing silica nanoparticles for applications including intracellular drug delivery and biosensing [66,67].

This advantage of synthesizing silica nanoparticles through the Stöber method suggests that silica coated over magnetite nanoparticles can significantly improve their stability for long-term storage conditions, thus retaining their medical properties by improving their shelf life. This is one of the crucial parameters for developing MRI-based contrast agents for clinical and commercial applications [68].

Besides the presented advantages of the Stöber method used for synthesizing silica nanoparticles, another important aspect is their functionalization with diverse materials to obtain novel nanostructures for biomedical applications. For instance, worth mentioning is that the preparation of $\mathrm{Fe}_{3} \mathrm{O}_{4} @ \mathrm{SiO}_{2}$ double layered with hydroxide core-shell resulted in microspheres with applications in protein separation and also the controllable fabrication of streptavidin-modified three-layer core-shell $\mathrm{Fe}_{3} \mathrm{O}_{4} / \mathrm{SiO}_{2} / \mathrm{Au}$ as a magnetic nanocomposite which has been demonstrated to have good applicability in fluorescence detection $[69,70]$.

The aim of this work highlights the synthesis methods for magnetite@silica nanoparticles to develop core@shell nanostructures, corroborating the synthesis routes with their characteristics. In this way, new strategies of functionalization were discovered. The most important aspects of this work are related to the applications and performance of magnetite@silica nanoparticles, especially in the biomedical field. The review is based on a literature search, using EndNote X9 distributed by Clarivate Analytics (US) LLC searching capability and limiting the search to the Web of Science Core Edition (Clarivate) database and the main keyword, $\mathrm{Fe}_{3} \mathrm{O}_{4} @ \mathrm{SiO}_{2}$. However, the information was further updated based on other additional searches.

\section{Synthesis of Magnetite-Silica Core/Shell Structures}

The most stated synthesis method for magnetite-silica core/shell nanostructures is the Stöber sol-gel method, which is a chemical synthesis route used to prepare silica shells of controllable and uniform size over the magnetite nanoparticle acting as a core [71].

The introduction describes the SPIONs as superparamagnetic iron oxide nanoparticles for biomedical applications. Besides the synthesis methods of the magnetite-silica core/shell structures, the process synthesis for SPIONs was also introduced. The litera- 
ture $[33,72]$ illustrates the synthesis methods for SPIONs such as gas deposition, thermal decomposition, hydrothermal, and other methods which have distinct procedures and different conditions for each type of nanoparticles. For SPION synthesis, the most used methods are co-precipitation and thermal decomposition [33].

It is important to mention that core/shell magnetic structures are developed to combine the advantages of the two layers; the magnetic one is responsible for the magnetic properties, while the shell ensures greater stability and can also bring new features. Besides the benefits of the core/shell nanostructures, more complex nanostructures with two or more shells are developed [73-75].

The methods of synthesis of nanoparticles were classified into two general categories, depending on the size of the precursors and their evolution. According to the used approaches, a bottom-up and a top-down approach of synthesis can be defined (Figure 1) [76]. The top-down technique requires resizing big particles into smaller particles, involving etching, grinding, and cutting techniques to shape them [77].

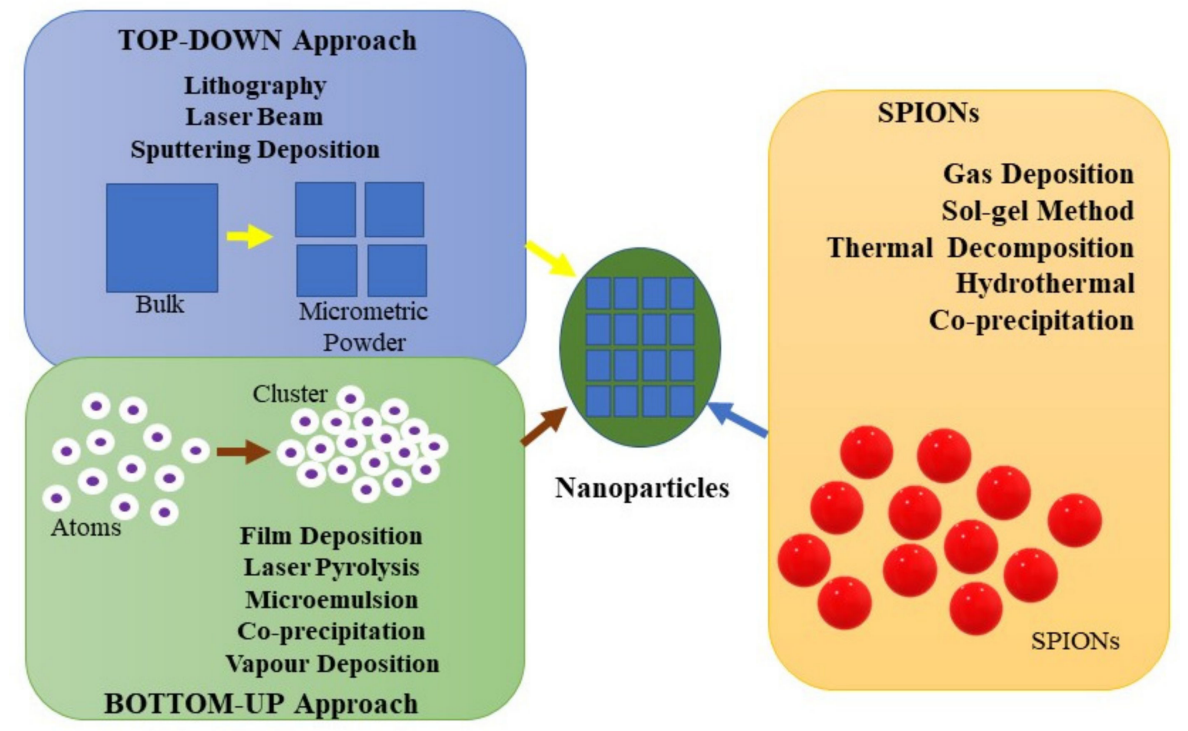

Figure 1. Nanoparticle's synthesis methods.

The bottom-up process starts from smaller units to obtain a larger one using the properties that smaller units have, only generating the desired size and form. Also, the bottom-up technique can be used to produce metal and metal oxide nanoparticles with proper size and shape which could bring great interest in desired applications [78-80]. In this way, only by adding an atom to an atom can the particle be formed into preferred sizes [77].

In continuation, Figure 1 describes some examples of the most used techniques, which include chemical vapour deposition [81,82], film deposition [83,84], laser pyrolysis [85,86], and others [87]. In the case of top-down approaches, the methods are different and involve mechanical techniques, laser beam processing [88,89], and lithography [6,90].

It was concluded that the synthesis of core@shell nanoparticles requires, especially, a bottom-up approach where the shell is built onto the magnetic core. To assist the synthesis of the core@shell structures and to control their characteristics, the method for preparing the core of nanoparticles can be either a top-down or a bottom-up approach; however, usually, the shell is obtained through a bottom-up approach, being more convenient for developing uniform coatings for the shell material over the core nanoparticles [4]. Through the top-down approach, significant crystallographic imperfections on the surface structure are developed, which is the major limitation of this method. Depending on the device design and fabrication, these limitations might conduct in supplementary manufacturing challenges. In comparison with the top-down approach, the bottom-up approach has gained attention regarding its low cost and other advantages, such as preferential control 
over the manufacturing process, precision and low energy loss, and, most importantly, the formation of a smaller particle size [4]. Therefore, depending on the synthesis methods, the methods in which core@shell nanoparticles are manufactured are divided into two types: (1) in situ synthesis followed up by coating the shell material coating [91-93]; (2) core@shell formation through different methods [94-96]. The methods have similarities that showed changes in particle size, surface reactivity, and the composition of the core@shell, and optical and magnetic properties of the constituent parts confirmed the formation of the core@shell nanostructures $[91,92,94]$. The results also showed that the synthesis of core@shell nanostructures via the methods described presented magnetic and biocatalytic applications [91,92]. The bottom-up approach is more useful than the top-down approach, as it is more proper for the preparation of materials at the nanoscale and generates uniform size, shape, and distribution. Top-down routes are not suitable for preparing uniform shapes and are difficult to design nanoparticles with, with the biggest problem being designing an imperfect surface structure. It has been reported that the grinding technique has been successfully used in the synthesis of magnetite nanoparticles by a topdown approach and that it significantly reduced the grinding time to $5 \mathrm{~h}$ compared to the previously reported studies $[73,97]$. With the help of top-down nanofabrication techniques such as lithography, monodispersed particles with controlled shapes and dimensions can be generated. The top-down approach used to synthesize nanoparticles proves to be an alternative to overcome the disadvantages and obstacles of the bottom-up method [98,99]. The approaches described above have multiple advantages and disadvantages; however, comparing the two techniques has shown that the bottom-up method is cost-effective and facilitates the manufacturing of 2D and 3D materials with multiple applications [78].

Table 1 describes various core@shell nanoparticles, their synthesis methods, and their application.

Table 1. Various core/shell nanoparticles and their synthesis methods and applications [4].

\begin{tabular}{|c|c|c|c|c|c|c|}
\hline $\begin{array}{l}\text { Core-Shell } \\
\text { Nanoparticles }\end{array}$ & Core & Shell & Methods of Synthesis & Size $(\mathrm{nm})$ & Application & Reference \\
\hline $\begin{array}{l}\text { Core-shell } \\
\text { magnetite NPs }\end{array}$ & $\mathrm{Fe}_{3} \mathrm{O}_{4} \mathrm{NPs}$ & Chitosan & $\begin{array}{l}\text { Co-precipitation followed } \\
\text { by chitosan coating }\end{array}$ & $136 \pm 2.3$ & $\begin{array}{l}\text { The targeting carriers } \\
\text { improve the therapeutic } \\
\text { efficiency of the } \\
\text { anticancer drugs by } \\
\text { reducing the side effects. }\end{array}$ & [100] \\
\hline $\begin{array}{c}\mathrm{pH}-\text { responsive } \\
\text { theragnostic core-shell } \\
\text { corona NPs }\end{array}$ & $\mathrm{Fe}_{3} \mathrm{O}_{4}$ core & $\begin{array}{l}\text { BSA shell\& } \\
\text { PEG corona }\end{array}$ & $\begin{array}{l}\text { Thermal decomposition } \\
\text { followed by BSA coating }\end{array}$ & $50-85$ & $\begin{array}{l}\text { Prolonged drug release } \\
\text { and reduced the side } \\
\text { effects of the } \\
\text { chemotherapy. }\end{array}$ & [101] \\
\hline $\begin{array}{c}\mathrm{Fe}_{3} \mathrm{O}_{4} @ \mathrm{SiO}_{2}-\mathrm{NH}_{2} \\
\text { core-shell nanomaterials }\end{array}$ & $\mathrm{Fe}_{3} \mathrm{O}_{4} \mathrm{NPs}$ & $\mathrm{SiO}_{2}-\mathrm{NH}_{2}$ & Sol-gel process & $\sim 200$ & $\begin{array}{l}\text { As adsorbent for } \\
\mathrm{Pb} \text { (II) removal. }\end{array}$ & [102] \\
\hline $\begin{array}{l}\mathrm{Fe}_{3} \mathrm{O}_{4} / \mathrm{SiO}_{2} \\
\text { core-shell NPs }\end{array}$ & $\mathrm{Fe}_{3} \mathrm{O}_{4} \mathrm{NPs}$ & $\mathrm{SiO}_{2}$ & $\begin{array}{l}\text { Chemical co-precipitation } \\
\text { followed by coating with } \\
\text { silica shells by Stöber } \\
\text { method }\end{array}$ & 29 & $\begin{array}{l}\text { Adsorption of chiral } \\
\text { aromatic amino acids }\end{array}$ & [103] \\
\hline $\begin{array}{c}\text { Lectin-conjugated } \\
\mathrm{Fe}_{2} \mathrm{O}_{3} @ \mathrm{Au} \\
\text { core@shell NPs }\end{array}$ & $\mathrm{Fe}_{2} \mathrm{O}_{3} \mathrm{NPs}$ & $\mathrm{Au}$ & $\begin{array}{l}\text { Synthesis by redox } \\
\text { reactions }\end{array}$ & $22.1 \pm 1.9$ & $\begin{array}{l}\text { Using contrast agents for } \\
\text { in vivo detection } \\
\text { of tumour }\end{array}$ & [104] \\
\hline $\begin{array}{c}\text { Superparamagnetic } \\
\mathrm{Fe}_{3} \mathrm{O}_{4} @ \mathrm{SiO}_{2} \text { core-shell } \\
\text { nanostructures }\end{array}$ & $\begin{array}{l}\text { crystalline } \\
\text { magnetite cores }\end{array}$ & $\begin{array}{l}\text { amorphous silica } \\
\text { shell }\end{array}$ & Sol-gel approach & 5 & $\begin{array}{l}\text { Biomedical applications: } \\
\text { hyperthermia, MRI, } \\
\text { drug delivery systems. }\end{array}$ & [4] \\
\hline $\begin{array}{c}\mathrm{Fe}_{3} \mathrm{O}_{4} / \mathrm{SiO}_{2} \text { core } / \text { shell } \\
\text { nanocubes }\end{array}$ & $\begin{array}{l}\text { Core magnetite } \\
\text { nanocubes }\end{array}$ & Silica & $\begin{array}{l}\text { Sol-gel, thin, } \\
\text { microemulsion }\end{array}$ & $5-16$ & $\begin{array}{l}\text { Promising bio-sensing } \\
\text { applications using the } \\
\text { cubic structure of } \\
\text { magnetite NPs } \\
\text { functionalized with } \\
\text { silica. }\end{array}$ & [45] \\
\hline $\begin{array}{l}\text { Fucan-coated } \\
\text { magnetite NPs }\end{array}$ & $\begin{array}{l}\text { Fucan } \\
\text { polysaccharide } \\
\text { coating }\end{array}$ & Magnetite NPs & Co-precipitation & 10 & $\begin{array}{l}\text { Used as a protein in } \\
\text { enzyme immobilization, } \\
\text { bio-separation, MRI, } \\
\text { hyperthermia, } \\
\text { drug delivery. }\end{array}$ & [52] \\
\hline
\end{tabular}


Table 1. Cont

\begin{tabular}{|c|c|c|c|c|c|c|}
\hline $\begin{array}{c}\text { Core-Shell } \\
\text { Nanoparticles }\end{array}$ & Core & Shell & Methods of Synthesis & Size $(\mathrm{nm})$ & Application & Reference \\
\hline $\begin{array}{c}\mathrm{Fe}_{3} \mathrm{O}_{4} @ \mathrm{mSiO}_{2} \text { core-shell } \\
\text { nanostructures }\end{array}$ & $\begin{array}{l}\text { Superpara-magnetic } \\
\text { magnetite core }\end{array}$ & $\begin{array}{l}\text { Mesoporous } \\
\text { silica shells }\end{array}$ & A modified Stöber method & $200-250$ & $\begin{array}{l}\text { Targeted cancer and } \\
\text { non-cancer tumors in the } \\
\text { human body. }\end{array}$ & [105] \\
\hline $\begin{array}{l}\text { Amino-functionalized } \\
\mathrm{Fe}_{3} \mathrm{O}_{4} @ \mathrm{SiO}_{2} \text { core-shell } \\
\text { magnetic nanomaterial }\end{array}$ & Magnetite NPs & $\begin{array}{l}\text { Amino- } \\
\text { functionalized } \\
\text { silica shell }\end{array}$ & Co-precipitation method & $10-20$ & $\begin{array}{l}\text { Recyclable adsorbent for } \\
\text { the removal of heavy } \\
\text { metals from wastewater }\end{array}$ & [106] \\
\hline $\begin{array}{l}\text { Magnetite-silica } \\
\text { core-shell nanospheres } \\
\text { and nanocapsules }\end{array}$ & Magnetite core & Silica shell & $\begin{array}{l}\text { Magnetite core is obtained } \\
\text { by co-precipitation while } \\
\text { the silica shell is obtained } \\
\text { by modifying hydrolysis } \\
\text { and condensation using } \\
\text { tetraethyl orthosilicate }\end{array}$ & $\begin{array}{l}540 \pm 51 \\
149 \pm 19\end{array}$ & $\begin{array}{l}\text { A potential magnetic } \\
\text { candidate that targets } \\
\text { the treatment of } \\
\text { malignant tumours by } \\
\text { photodynamic therapy } \\
\text { (PDT). }\end{array}$ & [107] \\
\hline $\begin{array}{c}\text { Monodisperse } \\
\text { superparamagnetic } \\
\text { single-crystal magnetite } \\
\text { NPs with mesoporous } \\
\text { structure }\end{array}$ & Magnetite NPs & Silica shell & Solvothermal method & $70 \pm 10$ & $\begin{array}{l}\text { Drug loading ability and } \\
\text { favourable release } \\
\text { property for Dox with } \\
\text { promising applications } \\
\text { in drug delivery. }\end{array}$ & {$[34]$} \\
\hline $\begin{array}{c}\text { Silica-coated quasicubic } \\
\text { magnetite as a T2 } \\
\text { contrast agent } \\
\left(\mathrm{Mag} @ \mathrm{SiO}_{2} \text { HER-2) }\right.\end{array}$ & Magnetite NPs & Silica shell & Controlled hydrolysis & $60 \pm 10$ & $\begin{array}{c}\mathrm{Mag} @ \mathrm{SiO}_{2} \mathrm{NPs} \\
\text { effectively used as a T2 } \\
\text { contrast agent in } \\
\text { commercial MRI. }\end{array}$ & [68] \\
\hline $\begin{array}{l}\text { Magnetite-silica } \\
\text { core-shell NPs }\end{array}$ & Magnetite NPs & Silica shell & $\begin{array}{c}\text { Magnetite NPs silica-shell } \\
\text { by adding CTAB@TEA@ } \\
\text { TEOS } \\
\text { as surfactants sol-gel }\end{array}$ & $25 \pm 5$ & $\begin{array}{l}\text { Magnetite-silica } \\
\text { core-shell NPs are used } \\
\text { in medical applications. }\end{array}$ & [108] \\
\hline $\begin{array}{c}\text { Core-shell } \\
\mathrm{Fe}_{3} \mathrm{O}_{4} @ \mathrm{SiO}_{2} \mathrm{NPs}\end{array}$ & Magnetite NPs & Silica shell & modified Stöber method & $\begin{array}{l}\text { Mag-20; } \\
\text { Silica } \\
12.5-45\end{array}$ & $\begin{array}{l}\text { These core-shell } \\
\mathrm{Fe}_{3} \mathrm{O}_{4} @ \mathrm{SiO}_{2} \mathrm{NPs} \text { with } \\
\text { controlled silica shell } \\
\text { thicknesses are used in } \\
\text { bio-conjugation } \\
\text { applications. }\end{array}$ & [43] \\
\hline $\begin{array}{c}\mathrm{Fe}_{3} \mathrm{O}_{4} @ \mathrm{~m}-\mathrm{SiO}_{2} @ \mathrm{Co}-\mathrm{Zr}- \\
\mathrm{Sb}\end{array}$ & Magnetite NPs & $\begin{array}{l}\text { Mesoporous } \\
\text { silica shell and } \\
\text { Co-Zr-Sb }\end{array}$ & $\begin{array}{l}\text { A three-step method was } \\
\text { applied involving the } \\
\text { synthesis of magnetite, } \\
\text { followed by coating with } \\
\text { mesoporous silica, and } \\
\text { finally, Co-Zr-Sb trimetallic } \\
\text { growth on the surface }\end{array}$ & - & $\begin{array}{l}\text { These core@shell@shell } \\
\text { structures are exploited } \\
\text { as a catalyst in the } \\
\text { reduction of nitroarenes } \\
\text { to azoxy arenes }\end{array}$ & [74] \\
\hline $\begin{array}{c}\mathrm{Fe}_{3} \mathrm{O}_{4} @ \mathrm{SiO}_{2} @ \mathrm{Au} @ \\
\text { Porous } \mathrm{SiO}_{2} \\
\text { Structure }\end{array}$ & Magnetite NPs & $\begin{array}{c}\mathrm{SiO}_{2} @ \mathrm{Au} @ \text { porous } \\
\mathrm{SiO}_{2}\end{array}$ & $\begin{array}{c}\mathrm{Fe}_{3} \mathrm{O}_{4} @ \mathrm{SiO}_{2} @ \text { Au@porous } \\
\mathrm{SiO}_{2} \text { can be obtained by a } \\
\text { step-by-step approach, } \\
\text { starting from magnetite, } \\
\text { followed by coating with a } \\
\mathrm{SiO}_{2} \text { layer and adsorbing } \\
\mathrm{Au} \text { onto the surface. After } \\
\text { an Au adsorption, an } \\
\text { additional } 20 \mathrm{~nm} \mathrm{SiO}_{2} \\
\text { layer is deposited and } \\
\text { etched to control the } \\
\text { degradation of } \mathrm{SiO}_{2} \text { in } \\
\mathrm{NaOH} .\end{array}$ & $70-100 \mathrm{~nm}$ & $\begin{array}{c}\text { These core@shell@shell } \\
\text { structures were } \\
\text { designed for magnetic } \\
\text { targeting and } \\
\text { doxorubicin delivery } \\
\text { from the second layer of } \\
\text { silica (mesoporous) with } \\
\text { the aid of Near-Infrared } \\
\text { irradiation. }\end{array}$ & [75] \\
\hline $\begin{array}{c}\mathrm{Fe}_{3} \mathrm{O}_{4} @ \mathrm{SiO}_{2} @ \mathrm{Kit}- \\
6 / \mathrm{NH}_{2}\end{array}$ & Magnetite NPs & $\mathrm{SiO}_{2} @ \mathrm{Kit}-6 / \mathrm{NH}_{2}$ & $\begin{array}{c}\text { The first step represents } \\
\text { the synthesis of the } \mathrm{Fe}_{3} \mathrm{O}_{4} \\
\text { core followed by an } \\
\text { intermediate silica shell } \\
\text { deposition because the last } \\
\text { step occurs in acidic } \\
\text { conditions, just to protect } \\
\text { magnetite. }\end{array}$ & $<50 \mathrm{~nm}$ & $\begin{array}{l}\text { These core@shell@shell } \\
\text { structures are designed } \\
\text { to adsorb specific dyes } \\
\text { from the water via the } \\
\text { immobilized amino } \\
\text { groups }\end{array}$ & [109] \\
\hline
\end{tabular}

The table above presents examples with various core/shell nanoparticles, their synthesis methods, and their applications, and, next, will summarize some of the most used methods of synthesis for magnetite-silica core/shell nanostructures. The selection of the synthesis methods for core and shell are very important and require good judgment in choosing the proper material for a better outcome regarding the final applications of the core-shell nanoparticles. For the formation of core, nanoparticles have been used and have gained great attention in therapeutic applications. Besides their core, metal nanoparticles are being used for drug delivery applications. Using quantum dots as the core and shell can entrap diverse drugs within and can develop interesting core-shell nanoparticles for 
theranostic applications. Considering the type of precursors used to prepare the core, different preparation methods are needed [6].

The nanoprecipitation method has the advantage of being simple, fast, and reproducible; it has been used widely in the fabrication of nanoparticles as well as nanocapsules. In this method, a few factors affect the physicochemical properties of the nanoparticles, such as concentration, nature, and concentration of surfactant/dispersing agents. These parameters can significantly influence the particle size and entrapment, as well as loading efficiency, when it comes to deciding on the proper applications $[6,110]$.

The coprecipitation method is the most widely used method for the synthesis of metal oxide nanoparticles with controlled size and magnetic properties. In this method, aqueous salt solutions are used as precursors, with the precipitation of the desired nanoparticles being controlled by the addition of an alkaline solution. Different factors, such as ionic strength, $\mathrm{pH}$, and temperature of the reaction system, as well as the nature of the precursors, highly influence the morphology and composition of the magnetic nanoparticles [6].

Therefore, Farimani et al. [4] describe an approach based on the preparation of electrostatically stabilized $\mathrm{Fe}_{3} \mathrm{O}_{4}$ nanoparticles as seeds synthesized by the Stöber method. They used stabilized trisodium citrate molecules to change surfaces and cover the magnetite nanoparticles with silica. In Mitra's work, as mentioned above, $\mathrm{Fe}_{3} \mathrm{O}_{4} @ \mathrm{SiO}_{2}$ core/shell nanocomposites were synthesized through a sol-gel method and were considered promising tools in various biomedical applications such as targeted drug delivery, magnetic hyperthermia, MRI, and bio-separation [111-113].

Alternatively, the shape of the magnetite nanoparticles is an important aspect when it comes to evaluating their bio-applications; in this case, nanocubes are attractive options in terms of surface/volume ratio, which means an increase in biomolecules on the surface. The synthesis of $\mathrm{Fe}_{3} \mathrm{O}_{4} / \mathrm{SiO}_{2}$ core/shell nanocubes structures was performed in two steps $[114,115]$. The first one consists of the synthesis of magnetite hydrophilic nanocubes, which is performed by a sonochemical method, and then the magnetite nanocubes obtained are taken from the precipitate using a magnet. Besides, the surface of the magnetite nanocube is functionalized through a modified sol-gel method. The obtained precipitate is collected and dried. If core/shell nanocubes with different thicknesses are desired to be developed, the amount of TEOS in the reaction must be controlled [45]. One of the syntheses of silica magnetite nanoparticles has been used oleic acid as a surfactant to stabilize the magnetite core on the silica shell [116].

Depending on the applications and conditions of synthesis, such as $\mathrm{pH}$, temperature, stabilizing agents, and reaction time, the size, morphology, and even the magnetic properties of nanoparticles can be tuned [33]. To obtain core-shell magnetic nanoparticles for biomedical application, it is necessary to overcome some constraints on the $\mathrm{Fe}_{3} \mathrm{O}_{4}$ effects on the blood as well as its limited stability in blood circulation. The above limitations can be resolved by functionalizing ionic oxides with stabilizers [117,118]. The $\mathrm{Fe}_{3} \mathrm{O}_{4} @ \mathrm{SiO}_{2}$ preparation starts from the microemulsion water-oil, where nanocomposites are formed due to silica's ability to coat hydrophobic nanoparticles [5].

The solvothermal methods are based on the assistance of the temperature and pressure to form metal oxide nanoparticles. The solvothermal method is superior, concerning control of particle size and shape distributions, along with crystallinity, compared to the classical precipitation methods [6]. Using this synthesis method, monodisperse superparamagnetic single-crystal magnetite nanoparticles (MSSMN) were obtained [34]. These obtained materials were characterized by their morphology and crystalline structure, resulting in nanoparticles with a size of $70 \mathrm{~nm}$. The most interesting aspect was that the magnetite nanoparticles had mesoporous structures, having a pore size of $5-10 \mathrm{~nm}$. The energy-dispersive X-ray spectroscopy (EDS) and photoelectron spectroscopy (XPS) tests proved that the $\mathrm{Fe}_{3} \mathrm{O}_{4}$ NPs are a pure phase. Besides, in the analysis of transmission electron microscopy (TEM), a thin shell of silica was observed to be coated on the core of $\mathrm{Fe}_{3} \mathrm{O}_{4}$ NPs [34]. It has been shown that the change in the amount of sodium hydroxide $(\mathrm{NaOH})$ controls the size of the mesoporous $\mathrm{Fe}_{3} \mathrm{O}_{4} \mathrm{NPs}$, which shows that an excess of 
sodium hydroxide impacts the formation of irregular mesoporous $\mathrm{Fe}_{3} \mathrm{O}_{4} \mathrm{NPs}$. This porous material was designed to incorporate drugs or genes into functionalized pores, which demonstrated that MSSMN has applications in drug delivery [34]. The titanium dioxide catalyst $\left(\mathrm{TiO}_{2}\right)$ (including the photocatalyst) properties were used to develop nanomaterials with increased photoreactivity. Some researchers have coated the magnetite with silica $\left(\mathrm{SiO}_{2}\right)$, followed by coating with a further $\mathrm{TiO}_{2}$ shell through a facile and effective sol-gel method sustained by sonication. The photocatalytic assessment of the $\mathrm{Fe}_{3} \mathrm{O}_{4} / \mathrm{SiO}_{2} / \mathrm{TiO}_{2}$ core-shell/shell nanoparticles was conducted with or without UV irradiation. Based on the TEM evaluation, the $\mathrm{Fe}_{3} \mathrm{O}_{4} / \mathrm{SiO}_{2}$ core-shell nanoparticles have approximately $120 \mathrm{~nm}$ and the $\mathrm{TiO}_{2}$ layer has $20-30 \mathrm{~nm}$, meaning that the $\mathrm{Fe}_{3} \mathrm{O}_{4} / \mathrm{SiO}_{2} / \mathrm{TiO}_{2}$ core/shell/shell structures have $\sim 150 \mathrm{~nm}[119,120]$.

The silica-coated magnetite nanoparticles can be used as T2-weighted MRI contrast agents for theranostic [33]. The usual method used for the manufacturing of magnetic nanoparticles was thermal decomposition followed by coating with silica shell by controlled hydrolysis [68]. Based on the TEM, it has been demonstrated that the particles have polydispersion and quasi-cubic morphology, with particles ranging from 40 to $60 \mathrm{~nm}$, and with the silica shell being approximately $20 \mathrm{~nm}$. The conclusion indicated that $\mathrm{Fe}_{3} \mathrm{O}_{4} @ \mathrm{SiO}_{2}$ nanoparticles are used as an effective tool in the T2-weighted MRI contrast agent within the tissue $[68,121]$.

Another study reported the core-shell magnetite-silica nanoparticle synthesis through two steps [108]. In the first phase, the synthesis of magnetite nanoparticles was performed by a coprecipitation method followed by the silica shell obtained with the addition of cetyltrimethylammonium bromide (CTAB), triethanolamine (TEA), and tetraethyl orthosilicate (TEOS) as surfactants, and a precursor for the silica shell formation via a sol-gel process. To use these magnetite-silica core-shell nanoparticles in specific applications, the pore characteristics from the silica shell should be controlled. The main aspects to be studied were the diameter of the pores, the volume of pores, and the surface area [108]. Through the analysis of the surface area of Brunauer-Emmett-Teller (BET), it was possible to determine the surface area of the pores of $177 \mathrm{~m}^{2} / \mathrm{g}$; the pore size was $5.25 \mathrm{~nm}$, and the model was the adsorption of gas. In the Barrett-Joyner-Halenda (BJH) pore size and volume analysis, the pore size distributions were estimated using the Kelvin model in the pore filling. One of the most important features that is also considered is the magnetic effect, evaluated using a vibrating sample magnetometer (VSM), measuring $60 \mathrm{emu} / \mathrm{g}$. The images of the transmission electron microscopy (TEM) confirmed that the cores are uniformly surrounded by shells with an average particle size of $25 \mathrm{~nm}$ [108].

In their work, Hui et al. [43] reported a modified Stöber method for $\mathrm{Fe}_{3} \mathrm{O}_{4} @ \mathrm{SiO}_{2}$ core/shell nanoparticles using $20 \mathrm{~nm}$ hydrophilic $\mathrm{Fe}_{3} \mathrm{O}_{4}$ NPs as seeds. This paper is relevant for synthesis, which interests us in manipulating the magnetic properties of silica/magnetite nanocomposite materials by controlling their surface properties and silica coating thickness [122]. The X-ray diffraction (XRD) results were confirmed by the TEM data that concluded that the magnetite core is of a single crystallite size. These $\mathrm{Fe}_{3} \mathrm{O}_{4} @ \mathrm{SiO}_{2}$ core/shell nanoparticles with controlled shell thickness are used in bioconjugation applications [43].

Another study reported the synthesis using a modified Stöber method that was applied for the magnetite-silica nanostructures having $30-40 \mathrm{~nm}$ in diameter when the silica shell coats the magnetic nanoparticles. To use magnetite nanoparticles as a magnetic part in nanocomposites, they should be stabilized [43]. This paper supports the possible use of the magnetic properties of silica-magnetite composites, only stipulating that their properties and the thickness of the silica coating should be controlled. The study implies that the support of adequate encapsulation of magnetic nanoparticles is imperative in preserving adequate superparamagnetic properties, and the possibility of synthesizing large magnetic nanocomposites persists if the appropriate silica shell separates the individual magnetite nanoparticles [122]. 
The core/shell nanostructures have brought great attention to developing structures because the core and shell contribution is essential in tuning the performances of these structures. Here, the first shell mainly ensures stability (even during future shell deposits), while the outer layers assure activity. This example is linked to the $\mathrm{Fe}_{3} \mathrm{O}_{4} @ \mathrm{SiO}_{2} @ \mathrm{Au} @$ porous $\mathrm{SiO}_{2}$ structures in which the $\mathrm{SiO}_{2}$ layer covering the $\mathrm{Fe}_{3} \mathrm{O}_{4}$ core also supports the Au layer capable of generating mild photothermal, which is generated by NIR irradiation and can lead to faster delivery of the doxorubicin housed in the external porous $\mathrm{SiO}_{2}$ layer [75]. In this way, additional control of the delivery rate can be considered, and the delivery can be enhanced, when needed, in a stimuli-responsive way. External control is also important and can be considered anytime to assure personalized therapy.

The coating (shell) of the magnetic structure can be dense or porous, depending on the specific properties and applications. Dense shells are desired, especially when the core is exposed to harsh conditions, having a protective role, and porous structures are developed specifically for loading biologically active agents within their pores followed by their controlled release [75]. Silica is an important support material for binding different functionalities on its surface to develop multifunctional core@shell nanoparticles with precise biomedical applications. In this context, nanocomposites have become the ultimate trend solution for tumor imaging and treatment. Nanocomposite functionalized with silica could provide biocompatibility, polyfunctionality, and assure a controllable release of the drugs in the targeted cells [45].

Another interesting application of $\mathrm{Fe}_{3} \mathrm{O}_{4} / \mathrm{SiO}_{2}$ nanoparticles is in adsorbent applications for $\mathrm{Zn}$ removal from aqueous systems. Subsequent studies revealed that superparamagnetic core-shell $\mathrm{Fe}_{3} \mathrm{O}_{4} / \mathrm{SiO}_{2}$ nanoparticles are used in various bioconjugation applications [10,58].

\section{Surface Functionalization}

Promising biomedical applications can be achieved through surface functionalization of the magnetic core. As has already been discussed, the surface features of nanoparticles are important aspects that must be considered in functionalization. Based on these assumptions, significant progress has been made in the preparation of magnetic nanoparticles with specific properties for certain biomedical applications. Such examples include stabilization agents such as chelating organic anions (citric acid, palmitic acid, gluconic acid, oleic acid, amino acid [123,124]), inorganic shells—-metal or metal oxides (copper, silica)—or polymeric agents such as dextran, alginate, chitosan, etc. [125], as presented in Figure 2.

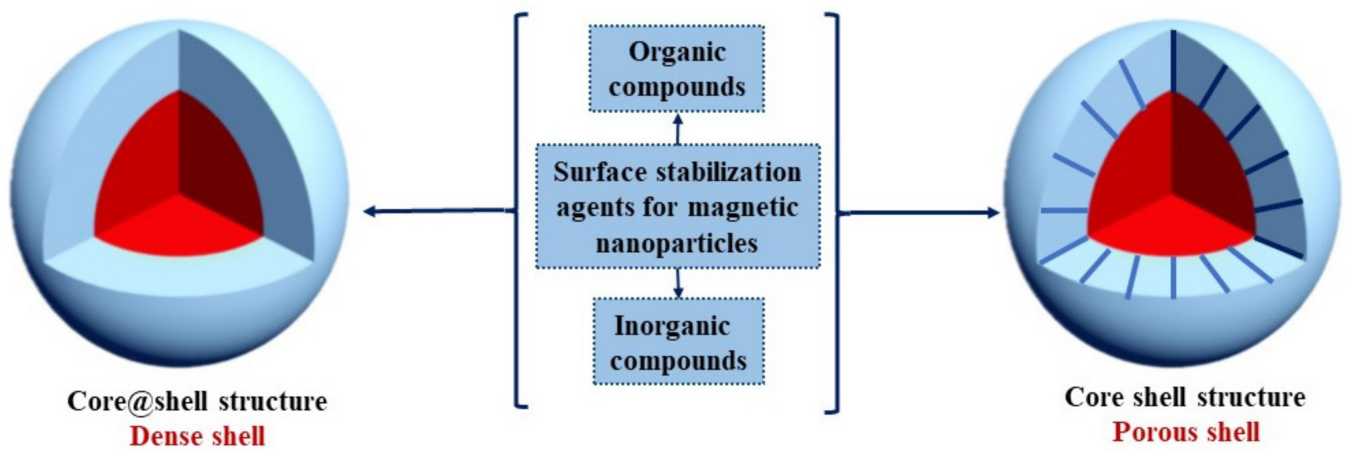

Figure 2. Surface stabilization protocols in developing porous versus non-porous core@shell magnetic nanostructures.

Figure 2 is a representation of surface functionalization in developing both dense and porous core@shell structures. Under certain conditions, a combined approach can be used, such as the core@shell@shell structures, such as even $\mathrm{Fe}_{3} \mathrm{O}_{4} @ \mathrm{SiO}_{2} @ \mathrm{mSiO}_{2}$ core@shell@shell developed by Yang et al. [75] from $\mathrm{Fe}_{3} \mathrm{O}_{4}$ and two layers of silica, the internal one being dense, while the exterior is mesoporous. Many biomedical applications are reported for mesoporous silica, as well as for the diagnosis and treatment of cancer and diabetes [126], 
thus offering the premises that, for these $\mathrm{Fe}_{3} \mathrm{O}_{4} @ \mathrm{SiO}_{2} @ \mathrm{mSiO}_{2}$ core@shell@shell structures to be used in such applications, the core must be additionally protected.

The $\mathrm{Fe}_{3} \mathrm{O}_{4} / \mathrm{SiO}_{2}$ core-shell nanocubes have good biomedical applications and their loading with streptavidin, the most common globular protein used in imaging, detection, drug delivery, and surface modification, has confirmed the ability of these nanocubes to bind to biomolecules. Furthermore, the stability of core-shell nanostructures is critical in practical applications, the core-shell $\mathrm{Fe}_{3} \mathrm{O}_{4} / \mathrm{SiO}_{2}$ nanocubes preparations have been examined and the tests confirmed the stability of core/shell nanocubes against severe conditions by reconstructing the samples coated in the presence of gaseous hydrogen $[45,114]$. Another important aspect that needs to be taken into consideration, especially from the bioapplications point of view is biocompatibility, and studies in HeLa cells have shown good biocompatibility. In conclusion, the $\mathrm{Fe}_{3} \mathrm{O}_{4} / \mathrm{SiO}_{2}$ core/shell nanocubes, where magnetite nanocubes have been coated with uniform silica shells, make them suitable nanostructures for biosensing applications [12].

In the work conducted by Vegerhof et al. [57], stable magnetic nanoparticles of controllable particle size were successfully synthesized with high efficiency in hyperthermia applications. These results concluded that good heating rate and surface functionalization are a perfect synergy that helped to develop a nanomaterial with magnetic properties for biomedical applications, which are influenced by their surface characteristics $[4,53]$. To use magnetic nanoparticles in biomedical applications, it is necessary to be able to present tuneable surface characteristics. The literature provides many magnetic nanoparticles with great applications; however, the surface coating is highly studied to improve their required properties [41].

As is well known, the functionalization of silica-based materials can occur easily and lead to significant improvements from both loading and release capacity. In this attempt, $\mathrm{Fe}_{3} \mathrm{O}_{4} @ \mathrm{SiO}_{2}$ was functionalized by linking amino moieties, and these nanostructures can be further used for the immobilization of $5^{\prime}$-nucleotidase enzyme to detect cancer biomarkers. Therefore, Chapa Gonzalez et al. [127] developed magnetite nanoparticles to separate the $5^{\prime}$-nucleotidase enzymes (5eNT). Furthermore, magnetic nanoparticles were covered in a core/shell with silica, aminosilane, and a double shell of silica-aminosilane. An ScFv (fragment antibody) and anti-CD73 antibody were attached to the coated nanoparticles to separate the enzyme. The XRD patterns of the analyzed nanoparticles highlight a crystallite size of $12.8 \mathrm{~nm}$, which was similar to the values observed by TEM; this suggested that the magnetite nanoparticles are monocrystalline. TEM images showed an agglomeration of particles with a narrow distribution of $16 \pm 4 \mathrm{~nm}$. Also, through the FTIR technique, the coating of magnetite with silica was confirmed. Analyzing the magnetization, it was confirmed that the presence of the coating material decreased the magnetization. The magnetic separation of this enzyme with the fragment antibody was found to be $28 \%$ higher than for the anti-CD73 antibody, and the enzyme adsorption was improved with the double-shell structures due to the increased length of the polymer chain. Magnetite nanoparticles with a double shell (silica-aminosilane) were also found to be more sensitive than magnetite with a single shell in the detection of biomarkers [127].

Cyclodextrin glycosyltransferase (CGTase) from alkaliphilic Amphibacillus sp. NPST10 was immobilized on amino-functionalized silica magnetic magnetite nanoparticles to develop a suitable candidate for industrial applications of CGTase, as described by Ibrahim et al. [128]. The XRD patterns analysis revealed that the spinel magnetite has a pure phase of magnetite nanoparticles and TEM images showed broad distribution with a particle size of $50 \mathrm{~nm}$. Furthermore, FTIR measurements confirmed that the coating of magnetite nanoparticles with silica functionalized the nanoparticles with regards to aminopropyl groups. The results have proven significant improvement of the thermal and $\mathrm{pH}$ of CGTase upon immobilization. Moreover, the kinetic study showed higher enzyme affinity toward the substrate compared with free CGTase. The immobilized CGTase could retain $87 \%$ of its initial activity after five cycles of utilization, indicating that immobilized CGTase on $\mathrm{Fe}_{3} \mathrm{O}_{4} / \mathrm{NH}_{2}-\mathrm{SiO}_{2}$ has good durability and magnetic recovery. The improvement 
in kinetic and stability parameters of immobilized CGTase makes the proposed method a suitable candidate for industrial applications of CGTase [128].

Another study proposes an original synthesis method to modify, in one step, core/shell nanoparticles grafted with polymer and functionalized with amino groups. This method presented the PVA cross-linked onto superparamagnetic iron oxide nanoparticles (SPIONs) by the addition of silica precursors with and without amino groups. This study has proven that combining classical silica and amino-functionalized silica precursors at a volume ratio of 3/1 with PVA-coated SPIONs (PVA-SPIONs) allowed for an easier and better synthesis of core/shell silica/SPIONs with PVA covalently grafted onto their surface. In conclusion, precoating oxide nanoparticles with PVA and then using a classical sol-gel route to encapsulate them in silica shells is an interesting and promising method to develop biocompatible nanoparticles for industrialized nanomedicine [129]. The Figure 3 consists of a graphical representation of a surface functionalization model.

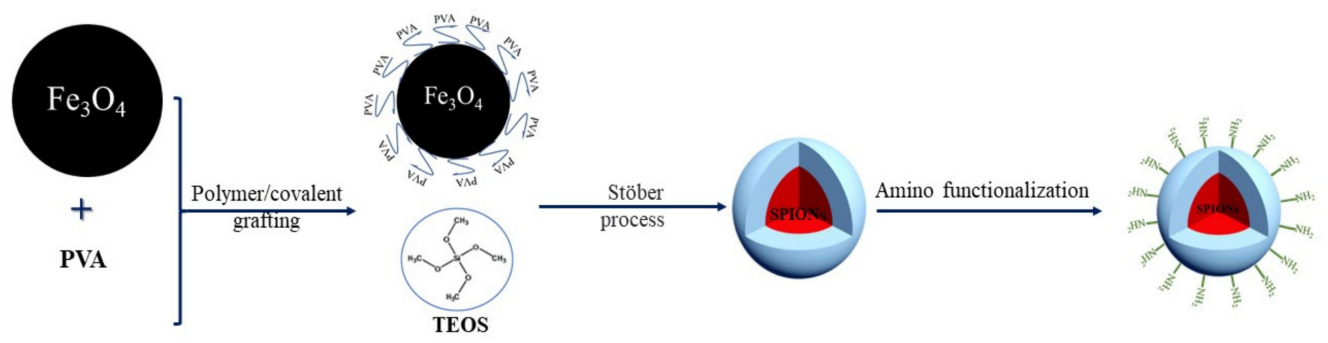

Figure 3. Graphical representation of a surface functionalization model.

Noma et al. [130] published a paper aiming to provide insights regarding acidic or basic modified particles that are more effective for enzyme immobilization; therefore, amino $\left(\mathrm{Fe}_{3} \mathrm{O}_{4} / \mathrm{SiO}_{2} / \mathrm{NH}_{2}\right)$ and carboxyl-functionalized $\left(\mathrm{Fe}_{3} \mathrm{O}_{4} / \mathrm{SiO}_{2} / \mathrm{COOH}\right)$ core-shell $\mathrm{Fe}_{3} \mathrm{O}_{4} / \mathrm{SiO}_{2}$ for L-asparaginase immobilization (ASNase) were prepared. Worth mentioning is that ASNase (EC 3.5.1.1) is an enzyme used effectively in anti-leukemia chemotherapy and is an essential amino acid for cancerous cells, but not for normal cells. Therefore, depending on the subject applications in sensor technology, the functionalization mechanisms are directly influenced by the level of asparagine presented in the blood circulation. Thanks to the $\mathrm{Fe}_{3} \mathrm{O}_{4} / \mathrm{SiO}_{2}$ modified with amino and carboxyl functional groups, it was possible for a facile immobilization of ASNase. FTIR, SEM, and EDX analysis to successfully confirm the presence of ASNase on the surface of $\mathrm{Fe}_{3} \mathrm{O}_{4} / \mathrm{SiO}_{2} / \mathrm{NH}_{2}$ and $\mathrm{Fe}_{3} \mathrm{O}_{4} / \mathrm{SiO}_{2} / \mathrm{COOH}$ particles. Moreover, $\mathrm{Fe}_{3} \mathrm{O}_{4} / \mathrm{SiO}_{2} / \mathrm{NH}_{2} / \mathrm{ASNase}$ and $\mathrm{Fe}_{3} \mathrm{O}_{4} / \mathrm{SiO}_{2} / \mathrm{COOH} / \mathrm{ASNase}$ exhibited good reusability. However, $\mathrm{Fe}_{3} \mathrm{O}_{4} / \mathrm{SiO}_{2} / \mathrm{NH}_{2} / \mathrm{ASN}$ ase showed more stability than $\mathrm{Fe}_{3} \mathrm{O}_{4} / \mathrm{SiO}_{2} / \mathrm{COOH} / \mathrm{ASN}$ ase because of many possible interactions and conformational stability. Cumulatively, $\mathrm{Fe}_{3} \mathrm{O}_{4} / \mathrm{SiO}_{2} / \mathrm{NH}_{2}$ and $\mathrm{Fe}_{3} \mathrm{O}_{4} / \mathrm{SiO}_{2} / \mathrm{COOH}$ particles are very promising supports for ASNase immobilization, providing multiple attachments between the enzyme and support, and resulting in excellent stabilization [130].

\section{Biomedical Applications}

This section of the review will display recent studies regarding magnetic nanoparticles which have garnered great interest regarding the most important techniques used in biomedical applications. One of them, the MRI, is a diagnostic technique used to visualize the internal structure of the body in detail. This technique has the advantage of obtaining a high display of soft tissues and is non-invasive, compared with computed tomography [131]. Also, unlike other diagnostic methods such as computed tomography (CT), sonography, nuclear scintigraphy, and X-ray imaging, MRI does not cause radiation damage and offers a high resolution of soft tissues which allows this method to be successfully applied to diagnosing a variety of diseases [7]. Along with the drug delivery capability of these systems, they can generate hyperthermia which can be used either to enhance delivery or to kill tumoral cells. Hyperthermia that treats cancer is also called thermal therapy, thermal ablation, or thermotherapy $[53,54,62,88]$. 
Andhariya et al. [107] developed core@shell nanostructures from modified silica magnetite nanoparticles loaded with a photosensitizer (PS) and a model drug "methylene blue" (MB) for biomedical applications such as drug delivery. The main concern of modern medicine is to treat cancer with few side effects. Based on this concept, photodynamic therapy (PDT) has been developed [132], in which certain photosensitizers (PS) were loaded into drug delivery vehicles (DDVs) because of their ability to induce photothermy or to assist the drug delivery in a personalized manner. First, the targeted place for the implementation of PS is reached and, then, through the irradiation, it is directed to a specific, targeted area. Even if PS touches normal tissues, it is toxic only when exposed to light, and thus no, or limited, side effects occur in healthy tissues. Oscar Raab was the first to initiate the PDT concept by using a dye as a PS in the photodynamic therapy. Studies concluded that acridine dye activated by light could kill paramecia, which was a finding that led to the basis of PDT $[133,134]$. More recent research has shown the significant progress that photosensitizers have brought to cancer treatments. Studies in clinical photodynamic therapy have received increased attention since the hospital administrations have permitted using photosensitizing drugs in curative and palliative treatments of diverse diseases $[135,136]$.

Studies conducted by Marinin [5] and Campbell et al. [137] confirmed that the magnetite core of the SPIONs coated with silica shells present promising applications in the biomedicine field, such as contrast agents for magnetic resonance imaging and drug delivery systems $[25,138]$.

Since ancient times, the early diagnosis of various diseases, such as cancer and sepsis, has always been a major problem of vital importance in medicine. Thus, special attention has been paid to the study of efficient methods of auxiliary diagnosis [1]. Magnetic resonance imaging (MRI) is one of the most powerful medical diagnostic methods that provides MRI imaging with excellent anatomical details based on soft-tissue contrast and functional information in a non-invasive method of real-time monitoring [6]. MRI results are strongly influenced by both the different imaging methods used in detecting and establishing medical problems, and the contrast agent (CA), which can significantly improve the contrast of biological targets around the tissue [9]. However, because the conventional contrast agent RM (CA) is expensive, and confers a low spatial resolution, early tiny tumours cannot be detected and, at the same time, no distinction can be made between benign and malignant tumours [8]. Therefore, the development of new CAs can effectively enhance the imaging effect.

Magnetic nanoparticles are also applied in biomedical applications using different stimuli, and each living system responds to stimuli, regardless of the type of stimuli, even if it is temperature, $\mathrm{pH}$, or light. Applying several stimuli to the body, we obtain an answer, and this response is vital for the proper operation of the whole system [108]. These features have been an inspiration for scientists to develop "smart" materials designed to react to various stimuli such as temperature, $\mathrm{pH}$, or magnetic field; as they are sensitive to a magnetic field, they can incorporate magnetic nanoparticles and lead to smart materials with good magnetic guidance and (magnetic) stimuli release. To transform energy into heat, magnetic particles were used as heat generators. The above phenomenon is important in cancer therapy because hyperthermia can be used in killing cancer cells, but also in targeted delivery, and increasing temperature will increase diffusion, therefore increasing the drug delivery [139]. Many studies have confirmed that nano-magnetic and microparticles have great applicability in magnetic storage media, biosensing and biomedical applications, as contrast agents in MRI-using them in tumor tissue under the action of magnetic fields-and also in new applications that aim to deliver and control the release of chemicals $[35,131,140]$.

Another good example of a multifunctional magnetic nanocomposite is $\mathrm{Fe}_{3} \mathrm{O}_{4} @ \mathrm{SiO}_{2}$, with biomedical applications related to the production of hyperthermia, which is an effective method to fight cancer. Hyperthermia is also combined with radiotherapy and chemotherapy, and is used to adjust the delivery rate of the chemotherapeutic drugs. 
The review describes the most important applications, and some of them are presented in this section. An important biomedical application worth mentioning is the use of magnetic nanomaterials in applications such as hyperthermia and controlled drug delivery $[4,53,54]$. As the term implies, hyperthermia means using heat in cancer therapy. Magnetic nanoparticle-based hyperthermia has proven to generate local heat that releases drugs at a specific site $[5,32,62,68,117,140-142]$. In medical hyperthermia, magnetic nanoparticles are used as a generator to raise tissue temperatures to 41 (mild) $-43^{\circ} \mathrm{C}$ (curative hyperthermia) in tumour cells, tissues, or organs. Coated magnetic nanoparticles can be functionalized/loaded with different molecules, such as drugs or antibodies, for use in targeted tumours from specific tissues/organs [35,143].

A new material synthesized by a solvothermal method with promising applications in drug delivery is monodisperse superparamagnetic single-crystal magnetite nanoparticles (MSSMN). Tests were conducted and the most important result stated that MSSMN is efficient in drug delivery applications. Doxorubicin (Dox) has been used as an anticancer drug, and the results have shown that these materials have a perfect loading capacity and favourable delivery profile for Dox $[4,5,34]$. Figure 4 is a graphical representation of the MSSMN synthesis as well as its use in biomedical applications.

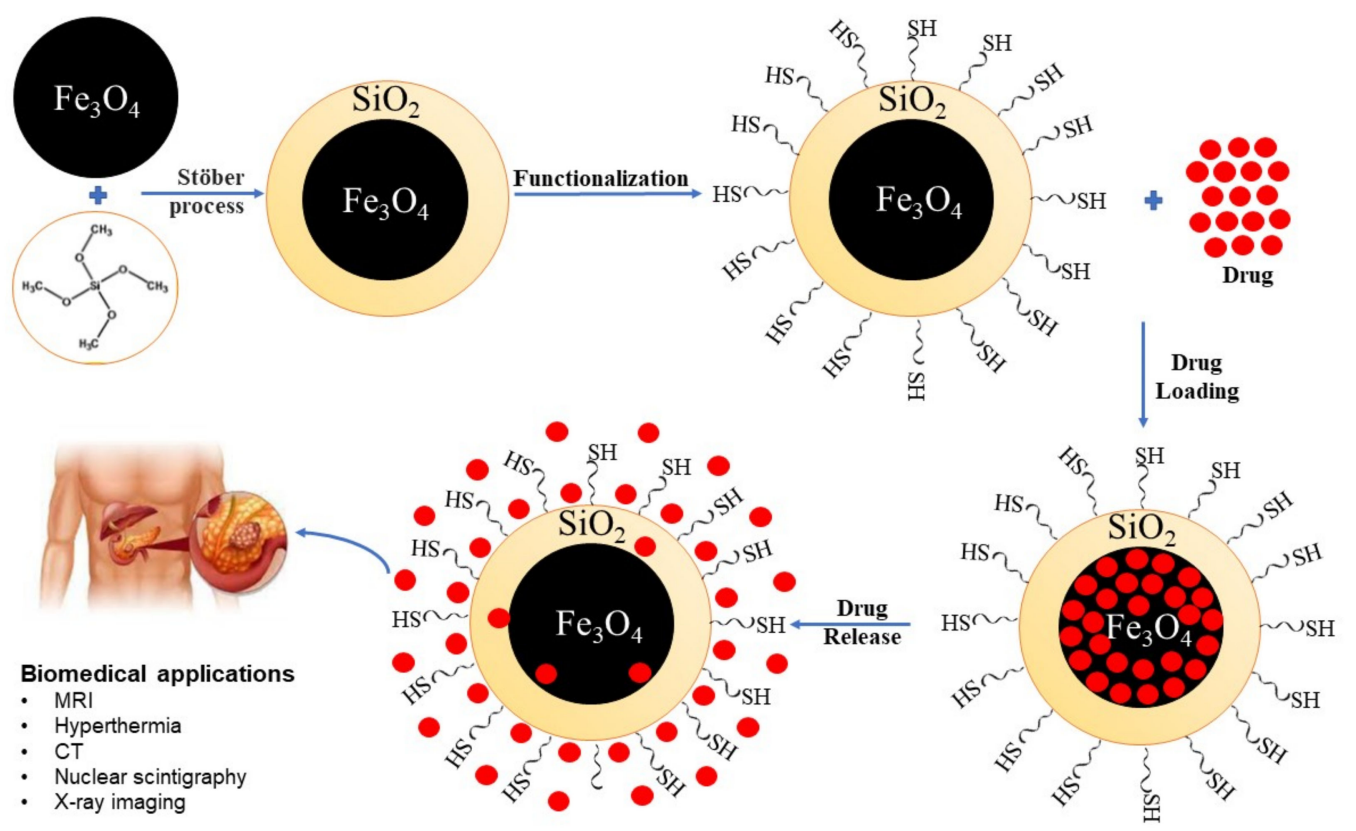

Figure 4. Graphical representation of biomedical applications.

Researchers are trying to develop certain modalities to control the transport of drugs and the rate of release, in a targeted way, on the specific tumour site. Through nanoengineering, an efficient drug delivery carrier was developed that can precisely localize the targeted tissue and release the perfect amount of medication that annihilates cancer without harming those in good health, which is the most desired challenge $[5,105,107]$.

After many studies, breast tumours are classified by histopathological degree, type, and stage; the classification was determined to find the best treatment, such as chemotherapy or immunotherapy $[33,101]$. Tumours were classified according to the epidermal growth of the factor receptor family in HER1, HER2, HER3, and HER4. Magnetite@silica nanoparticles proved to be biocompatible and excellent contrast agents in imaging studies through cellular magnetic resonance, and magnetite coated with silica showed great applicability for HER2 in targeting breast tumours. Magnetite coated with silica can be used in radiofrequency-induced heating techniques, as well as for the treatment of breast cancer $[5,68]$. 
Another interesting study that researched Alzheimer's disease investigated a new technique involving enzymes immobilized in magnetic microspheres through electrospray mass spectrometry (ESI-MS). To explain the model for immobilization of the acetylcholinesterase (AChE) enzyme on the modified 3-glycidoxypropyltrimethoxysilane (GLYMO) silica, the role of acetylcholinesterase (AChE) in the nervous system is demonstrated. The role of the enzyme was to transfer impulses to cholinergic synapses through an active neurotransmitter (acetylcholine) to inactive choline. It has been demonstrated that a reduction in AChE inhibition activity improves Alzheimer's treatment, leading to a slower progression of the disease [144].

Because of the properties of magnetic nanoparticles and their biocompatible character, they were used intensively in biomedical applications. By exposing them only to a magnetic field, magnetic nanoparticles are guided directly towards the tumor tissue, allowing nanomaterials to accumulate in the tumor. Because of the superparamagnetic and ferromagnetic properties, magnetic nanoparticles are used in MRI and hyperthermia techniques [145].

Azcona et al. [146] have synthesized, through a simple, traditional, and inverted coprecipitation method, highly suitable and promising magnetic nanosystems for diagnosis and therapeutic applications. One study revealed that the obtained nanomagnetic particles with supermagnetic properties, having a saturation magnetization of $88.1 \mathrm{emu} / \mathrm{g}$ and squareness ratio of 0.14 , can be used as a contrasting agent in magnetic resonance imaging (MRI) diagnosis [147].

For using magnetite nanoparticles for drug delivery, certain aspects have to be taken into consideration such as saturation magnetization, size, shape, surface charge, drug loading capacity, release rate, profile and factor, biocompatibility, and toxicity. Therefore, when selecting magnetite nanoparticles for drug delivery applications, they should be chosen carefully based on the mechanism of binding with other conjugates or else they can produce toxic effects that could harm the body system, which is not desirable [148].

\section{Conclusions}

This review highlights the synthesis methods for magnetite-silica core/shell nanostructures through different preparation routes and which have interesting applications in medical applications. Based on all the presented research, it has been shown that, for the preparation of magnetite nanoparticles coated with silica, the most used was the modified Stöber method. Although, there are still some difficulties to be achieved in the synthesis method of magnetic composites with tunable features. However, in addition to the Stöber method, other synthesis methods such as water-oil, micro-emulsion, gas deposition, coprecipitation, sol-gel, thermal deposition, and hydrothermal methods are presented.

In addition to the synthesis methods of magnetite-silica core/shell nanostructures, this review illustrates their characteristics and their superficial effects through functionalization, but also focuses on their applications, especially in the biomedical field such as hyperthermia, MRI, and drug delivery systems. From the presented research, it can be stated that magnetite-silica core/shell nanostructures have beneficial applications in many therapies and, through surface functionalization, they can load various drugs and further assist their delivery to obtain personalized therapy for the treatment and diagnosis of specific diseases, combining the benefits provided by the two components, the magnetic core and the silica shell. It is important to mention that core@shell@shell nanostructures are of growing interest and, most probable, their applications will be expanded and partially replace pure silica materials. Besides, great attention was devoted to the development of mesoporous shells that can host and release biologically active agents under triggered conditions that can be initiated by hyperthermia or other factors such as photothermy and $\mathrm{pH}$. It is worth mentioning that all the experimental research done in the biomedical field could provide promising outcomes and also show the potential of magnetite-silica core/shell nanostructures, and it is believed that their usage in clinical treatment is far from over. 
Author Contributions: This review was written with contribution from all authors, conceptualization, E.A. and A.F., methodology, A.S., C.-I.I., L.N.C. and A.F., validation, A.F. and D.F., writingoriginal draft preparation A.S., C.-I.I. and D.F.; writing-review and editing A.S., A.F. and E.A., visualization, A.F., L.N.C., D.F. and E.A., supervision A.F. and E.A. All authors have read and agreed to the published version of the manuscript.

Funding: This research was funded by UEFISCDI, grant number 522PED/2018 funded by UEFISCDI. The APC was funded by University POLITEHNICA of Bucharest.

Conflicts of Interest: The authors declare no conflict of interest.

\section{References}

1. Nicolas, J.; Mura, S.; Brambilla, D.; Mackiewicz, N.; Couvreur, P. Design, functionalization strategies and biomedical applications of targeted biodegradable/biocompatible polymer-based nanocarriers for drug delivery. Chem. Soc. Rev. 2013, 42, 1147-1235. [CrossRef] [PubMed]

2. Wong, I.Y.; Bhatia, S.N.; Toner, M. Nanotechnology: Emerging tools for biology and medicine. Genes Dev. 2013, 27, 2397-2408. [CrossRef] [PubMed]

3. Vo-Dinh, T. (Ed.) Nanotechnology at the Frontier of Biology and Medicine. In Methods, Devices and Applications; CRC Press: Boca Raton, FL, USA, 2017; pp. 1-16.

4. Farimani, M.H.R.; Shahtahmassebi, N.; Roknabadi, M.R.; Ghows, N. Synthesis and study of structural and magnetic properties of superparamagnetic $\mathrm{Fe}_{3} \mathrm{O}_{4} @ \mathrm{SiO}_{2}$ core-shell nanocomposite for biomedical applications. Nanomed. J. 2013, 1, 71-78.

5. Marinin, A. Synthesis and Characterization of Superparamagnetic Iron Oxide Nanoparticles Coated with Silica; Division of Functional Materials, Royal Institute of Technology, School of Information and Communication Technology Royal Institute of Technology: Stockholm, Sweden, 2012; p. 50.

6. $\quad$ Dhas, N.L.; Raval, N.J.; Kudarha, R.R.; Acharya, N.S.; Acharya, S.R. Core-shell nanoparticles as a drug delivery platform for tumor targeting. In Inorganic Frameworks as Smart Nanomedicines; Elsevier: Amsterdam, The Netherlands, 2018 ; pp. $387-448$.

7. Martins, C.; Chauhan, V.M.; Araújo, M.; Abouselo, A.; Barrias, C.C.; Aylott, J.W.; Sarmento, B. Advanced polymeric nanotechnology to augment therapeutic delivery and disease diagnosis. Nanomed. Nanotechnol. Biol. Med. 2020, 15, 2287-2309. [CrossRef] [PubMed]

8. Jiang, D.; Rosenkrans, Z.T.; Ni, D.; Lin, J.; Huang, P.; Cai, W. Nanomedicines for Renal Management: From Imaging to Treatment. Acc. Chem. Res. 2020, 53, 1869-1880. [CrossRef]

9. Dawson, P.; Romanowski, M. Designing ultraviolet upconversion for photochemistry. J. Lumin. 2020, 222, $117143-117155$. [CrossRef]

10. Younas, A.; Yousaf, Z.; Riaz, N.; Rashid, M.; Razzaq, Z.; Tanveer, M.; Huang, S. Role of Nanotechnology for Enhanced Rice Production. In Nutrient Dynamics for Sustainable Crop Production; Meena, R.S., Ed.; Springer: Singapore, 2019; pp. 315-350.

11. Dixit, S. Solar technologies and their implementations: A review. Mater. Today Proc. 2020, 28, 2137-2148. [CrossRef]

12. Khanal, L.R.; Sundararajan, J.A.; Qiang, Y. Advanced Nanomaterials for Nuclear Energy and Nanotechnology. Energy Technol. 2020, 8, 1901070. [CrossRef]

13. Gheisari, H.; Ghasemi-Kahrizsangi, S.; Karamian, E.; Nemati, A. Recent Advancement in monolithic refractories via application of Nanotechnology: A review paper. J. Nanoanal. 2019, 6, 1-20.

14. Zulfiqar, F.; Navarro, M.; Ashraf, M.; Akram, N.A.; Munné-Bosch, S. Nanofertilizer use for sustainable agriculture: Advantages and limitations. Plant Sci. 2019, 289, 110270-110281. [CrossRef]

15. Rajagopalan, M.; Darling, K.A.; Kale, C.; Turnage, S.A.; Koju, R.K.; Hornbuckle, B.C.; Mishin, Y.; Solanki, K.N. Nanotechnology enabled design of a structural material with extreme strength as well as thermal and electrical properties. Mater. Today 2019, 31, 10-20. [CrossRef]

16. Wang, D.; Saleh, N.B.; Sun, W.; Park, C.M.; Shen, C.; Aich, N.; Peijnenburg, W.J.G.M.; Zhang, W.; Jin, Y.; Su, C. NextGeneration Multifunctional Carbon-Metal Nanohybrids for Energy and Environmental Applications. Environ. Sci. Technol. 2019, 53, 7265-7287. [CrossRef]

17. KShah, W.; Xiong, T. Multifunctional Metallic Nanowires in Advanced Building Applications. Materials 2019, 12, $1731-1768$.

18. Peng, S.; Li, L.; Lee, J.K.Y.; Tian, L.; Srinivasan, M.; Adams, S.; Ramakrishna, S. Electrospun carbon nanofibers and their hybrid composites as advanced materials for energy conversion and storage-Review. Nano Energy 2016, 22, 361-395. [CrossRef]

19. Rickerby, D.G.; Morrison, M. Nanotechnology and the environment: A European perspective. Sci. Technol. Adv. Mat. 2007, 8, 19-24. [CrossRef]

20. Zhang, A.; Liu, R.; Tian, J.; Huang, W.; Liu, J. MXene-Based Nanocomposites for Energy Conversion and Storage Applications, Chemistry. Eur. J. 2020, 26, 6342-6359. [CrossRef]

21. Croitoru, A.M.; Ficai, A.; Ficai, D.; Trusca, R.; Dolete, G.; Andronescu, E.; Turculet, S.C. Chitosan/Graphene Oxide Nanocomposite Membranes as Adsorbents with Applications in Water Purification. Materials 2020, 13, 1687. [CrossRef]

22. Atabaki, A.H.; Moazeni, S.; Pavanello, F.; Gevorgyan, H.; Notaros, J.; Alloatti, L.; Wade, M.T.; Sun, C.; Kruger, S.A.; Meng, H.; et al. Integrating photonics with silicon nanoelectronics for the next generation of systems on a chip. Nature 2018, 55, 349-354. [CrossRef] 
23. Ismail, R. Novel device architectures and carbon based materials for future nanoelectronics. In Proceedings of the 2 nd International Conference on Information Technology, Computer, and Electrical Engineering (ICITACEE), Semarang, Indonesia, 16-18 October 2015; p. 1.

24. National Nanotechnology Initiative. Available online: http://www.nano.gov (accessed on 6 January 2020).

25. Neuberger, T.; Schöpf, B.; Hofmann, H.; Hofmann, M.; von Rechenberg, B. Superparamagnetic nanoparticles for biomedical applications: Possibilities and limitations of a new drug delivery system. J. Magn. Magn. Mater. 2005, 293, 483-496. [CrossRef]

26. Anderson, S.D.; Gwenin, V.V.; Gwenin, C.D. Magnetic Functionalized Nanoparticles for Biomedical, Drug Delivery and Imaging Applications. Nanoscale Res. Lett. 2019, 14, 188. [CrossRef]

27. Sarangapany, S.; Mohanty, K. Facile green synthesis of magnetically separable Au-Pt@TiO $\mathrm{T}_{2}$ nanocomposite for efficient catalytic reduction of organic pollutants and selective oxidation of glycerol. J. Alloys Compd. 2020, 830, 154636. [CrossRef]

28. Duy Vu Nguyen, K.; Dang Nguyen Vo, K. Magnetite nanoparticles- $\mathrm{TiO}_{2}$ nanoparticles-graphene oxide nanocomposite: Synthesis, characterization and photocatalytic degradation for Rhodamine-B dye. AIMS Mater. Sci. 2020, 7, 288-301. [CrossRef]

29. Khammar, S.; Bahramifar, N.; Younesi, H. Preparation and surface engineering of $\mathrm{CM}-\beta-\mathrm{CD}$ functionalized $\mathrm{Fe}_{3} \mathrm{O}_{4} @ \mathrm{TiO}_{2}$ nanoparticles for photocatalytic degradation of polychlorinated biphenyls (PCBs) from transformer oil. J. Hazard. Mater. 2020, 394, 122422-122438. [CrossRef]

30. Hashemi, S.Y.; Badi, M.Y.; Pasalari, H.; Azari, A.; Arfaeinia, H.; Kiani, A. Degradation of Ceftriaxone from aquatic solution using a heterogeneous and reusable $\mathrm{O}_{3} / \mathrm{UV} / \mathrm{Fe}_{3} \mathrm{O}_{4} @ \mathrm{TiO}_{2}$ systems: Operational factors, kinetics and mineralisation. Int. J. Environ. Anal. Chem. 2020, 1, 1-17. [CrossRef]

31. Boruah, P.K.; Das, M.R. Dual responsive magnetic $\mathrm{Fe}_{3} \mathrm{O}_{4}-\mathrm{TiO}_{2}$ /graphene nanocomposite as an artificial nanozyme for the colorimetric detection and photodegradation of pesticide in an aqueous medium. J. Hazard. Mater. 2020, 385, 121516. [CrossRef]

32. Durdureanu-Angheluta, A.; Pinteala, M.; Simionescu, B.C. Tailored and Functionalized Magnetite Particles for Biomedical and Industrial Applications. In Materials Science and Technology; Hutagalung, S., Ed.; InTech: London, UK, 2012; pp. 149-179.

33. Mahmoudi, M.; Sant, S.; Wang, B.; Laurent, S.; Sen, T. Superparamagnetic iron oxide nanoparticles (SPIONs): Development, surface modification and applications in chemotherapy. Adv. Drug Deliv. Rev. 2011, 63, 24-46. [CrossRef]

34. Guo, S.; Li, D.; Zhang, L.; Li, J.; Wang, E. Monodisperse mesoporous superparamagnetic single-crystal magnetite nanoparticles for drug delivery. Biomaterials 2009, 30, 1881-1889. [CrossRef]

35. Medeiros, S.F.; Santos, A.M.; Fessi, H.; Elaissari, A. Stimuli-responsive magnetic particles for biomedical applications. Int. J. Pharm. 2011, 403, 139-161. [CrossRef]

36. Chu, X.; Yu, J.; Hou, Y.-L. Surface modification of magnetic nanoparticles in biomedicine. Chin. Phys. B 2015, $24,14704-14712$. [CrossRef]

37. Smolensky, E.D.; Park, H.Y.; Berquo, T.S.; Pierre, V.C. Surface functionalization of magnetic iron oxide nanoparticles for MRI applications-Effect of anchoring group and ligand exchange protocol. Contrast Media Mol. Imaging 2011, 6, 189-200. [CrossRef]

38. Sun, B.; Zhou, G.; Zhang, H. Synthesis, functionalization, and applications of morphology-controllable silica-based nanostructures: A review. Prog. Solid State Chem. 2016, 44, 1-19. [CrossRef]

39. Christy, A.A. The Nature of Silanol Groups on the Surfaces of Silica, Modified Silica and Some Silica Based Materials. Adv. Mater. Res. 2014, 998-999, 3-10. [CrossRef]

40. Bitar, A.; Ahmad, N.M.; Fessi, H.; Elaissari, A. Silica-based nanoparticles for biomedical applications. Drug Discov. Today 2012, 17, 1147-1154. [CrossRef] [PubMed]

41. Liberman, A.; Mendez, N.; Trogler, W.C.; Kummel, A.C. Synthesis and surface functionalization of silica nanoparticles for nanomedicine. Surf. Sci. Rep. 2014, 69, 132-158. [CrossRef] [PubMed]

42. Dagher, S.; Soliman, A.; Ziout, A.; Tit, N.; Hilal-Alnaqbi, A.; Khashan, S.; Alnaimat, F.; Qudeiri, J.A. Photocatalytic removal of methylene blue using titania- and silica-coated magnetic nanoparticles. Mater. Res. Express 2018, 5, 065518. [CrossRef]

43. Hui, C.; Shen, C.; Tian, J.; Bao, L.; Ding, H.; Li, C.; Tian, Y.; Shi, X.; Gao, H.J. Core-shell $\mathrm{Fe}_{3} \mathrm{O}_{4} @ \mathrm{SiO}_{2}$ nanoparticles synthesized with well-dispersed hydrophilic $\mathrm{Fe}_{3} \mathrm{O}_{4}$ seeds. Nanoscale 2011, 3, 701-706. [CrossRef]

44. Roca, A.G.; Carmona, D.; Miguel-Sancho, N.; Bomatí-Miguel, O.; Balas, F.; Piquer, C.; Santamaría, J. Surface functionalization for tailoring the aggregation and magnetic behaviour of silica-coated iron oxide nanostructures. Nanotechnology 2012, $23,155603$. [CrossRef]

45. Abbas, $\mathrm{M} . \mathrm{Fe}_{3} \mathrm{O}_{4} / \mathrm{SiO}_{2}$ Core/Shell Nanocubes: Novel Coating Approach with Tunable Silica Thickness and Enhancement in Stability and Biocompatibility. J. Nanomed. Nanotechnol. 2014, 5, 1-8. [CrossRef]

46. Eun-Ji Woo, K.M.P.; Kim, K.-M.; Lee, C.-H. Effect of Surface Ligands of Magnetic Core-Shell Nanoparticle on Adsorptive Enzyme Immobilization; Yonsei University: Seoul, Korea, 2008; pp. 1-8.

47. Luborsky, F.E.; Drummond, B.J.; Penta, A.Q. Recent advances in the removal of magnetic foreign bodies from the esophagus, stomach and duodenum with controllable permanent magnets. Eye Ear Nose Throat. Mon. 1965, 44, 66-72. [PubMed]

48. Douglas, S.A.; Mirza, S.; Stafford, F.W. Magnetic removal of a nasal foreig. Int. J. Pediatric Otorhinolaryngol. 2002, 62, 165-167. [CrossRef]

49. Gillies, G.T.; Ritter, R.C.; Broaddus, W.C.; Grady, M.S.; Howard, M.A.; McNeil, R.G. Magnetic manipulation instrumentation for medical physics research. Rev. Sci. Instrum. 1994, 65, 533-562. [CrossRef]

50. Issa, B.; Obaidat, I.M.; Albiss, B.A.; Haik, Y. Magnetic nanoparticles: Surface effects and properties related to biomedicine applications. Int. J. Mol. Sci. 2013, 14, 21266-21305. [CrossRef] [PubMed] 
51. Mahmed, N. Development of Multifunctional Magnetic Core Nanoparticles; Department of Materials Science and Engineering, Universiti Malaysia Perlis: Kuala Lumpur, Malaysia, 2013; p. 195.

52. Silva, V.A.J.; Andrade, P.L.; Silva, M.P.C.; Bustamante, D.A.; De Los Santos Valladares, J.L. Albino Aguiar, Synthesis and characterization of Fe3O4 nanoparticles coated with fucan polysaccharides. J. Magn. Magn. Mater. 2013, 343, 138-143. [CrossRef]

53. Tran, N.; Webster, T.J. Magnetic nanoparticles: Biomedical applications and challenges. J. Mater. Chem. 2010, $20,8760-8767$. [CrossRef]

54. Tapeinos, C. Magnetic Nanoparticles and Their Bioapplications. In Smart Nanoparticles for Biomedicine; Elsevier: Amsterdam, The Netherlands, 2018; pp. 131-142.

55. Ortega, G.; Reguera, E. Chapter 13-Biomedical applications of magnetite nanoparticles. In Materials for Biomedical Engineering; Holban, A.-M., Grumezescu, A.M., Eds.; Elsevier: Amsterdam, The Netherlands, 2019; pp. 397-434.

56. Zhang, H.; Liu, X.L.; Zhang, Y.F.; Gao, F.; Li, G.L.; He, Y.; Peng, M.L.; Fan, H.M. Magnetic nanoparticles based cancer therapy: Current status and applications. Sci. China Life Sci. 2018, 61, 400-414. [CrossRef]

57. Vegerhof, A.; Motei, M.; Rudinzky, A.; Malka, D.; Popovtzer, R.; Zalevsky, Z. Thermal therapy with magnetic nanoparticles for cell destruction. Biomed. Opt. Express 2016, 7, 4581-4594. [CrossRef]

58. Bilal, M.; Zhao, Y.; Rasheed, T.; Iqbal, H.M.N. Magnetic nanoparticles as versatile carriers for enzymes immobilization: A review. Int. J. Biol. Macromol. 2018, 120, 2530-2544. [CrossRef]

59. Vaghari, H.; Jafarizadeh-Malmiri, H.; Mohammadlou, M.; Berenjian, A.; Anarjan, N.; Jafari, N.; Nasiri, S. Application of magnetic nanoparticles in smart enzyme immobilization. Biotechnol. Lett. 2016, 38, 223-233. [CrossRef]

60. Wilhelm, C.; Gazeau, F. Universal cell labelling with anionic magnetic nanoparticles. Biomaterials 2008, 29, 3161-3174. [CrossRef]

61. Marszall, M.P. Application of magnetic nanoparticles in pharmaceutical sciences. Pharm. Res. 2011, 28, 480-483. [CrossRef]

62. Kumar, C.S.; Mohammad, F. Magnetic nanomaterials for hyperthermia-based therapy and controlled drug delivery. Adv. Drug Deliv. Rev. 2011, 63, 789-808. [CrossRef] [PubMed]

63. Sun, Y.; Duan, L.; Guo, Z.; DuanMu, Y.; Ma, M.; Xu, L.; Zhang, Y.; Gu, N. An improved way to prepare superparamagnetic magnetite-silica core-shell nanoparticles for possible biological application. J. Magn. Magn. Mater. 2005, 285, 65-70. [CrossRef]

64. Stöber, W.; Fink, A.; Bohn, E. Controlled growth of monodisperse silica spheres in the micron size range. J. Colloid Interfaces Sci. 1968, 26, 62-69. [CrossRef]

65. Guido, K. Nanoparticles and Composites. In The Sol-Gel Handbook-Synthesis, Characterization, and Applications: Synthesis, Characterization and Applications; Levy, D., Zayat, M., Eds.; Wiley-VCH: Weinheim, Germany, 2015; pp. $225-244$.

66. Quignard, S.; Masse, S.; Coradin, T. Silica-Based Nanoparticles for Intracellular Drug Delivery. In Intracellular Delivery: Fundamentals and Applications; Prokop, A., Ed.; Fundamental Biomedical Technologies; Springer: Berlin/Heidelberg, Germany, 2011; pp. 333-361.

67. Ju, H.; Zhang, X.; Wang, J. Biosensors Based on Sol-Gel Nanoparticle Matrices. In NanoBiosensing: Principles, Development and Application; Springer: Berlin/Heidelberg, Germany, 2011; pp. 305-332.

68. Campbell, J.L. Magnetite-Silica Core-Shell Nanoparticles for HER-2 Targeted Magnetic Resonance Imaging of Breast Tumours; School of Applied Sciences-RMIT University: Melbourne, VIC, Australia, 2013; p. 190.

69. Shao, M.; Ning, F.; Zhao, J.; Wei, M.; Evans, D.G.; Duan, X. Preparation of $\mathrm{Fe}_{3} \mathrm{O}_{4} @ \mathrm{SiO}_{2} @$ Layered Double Hydroxide Core-Shell Microspheres for Magnetic Separation of Proteins. J. Am. Chem. Soc. 2012, 134, 1071-1077. [CrossRef] [PubMed]

70. Jiang, H.; Zeng, X.; Xi, Z.; Liu, M.; Li, C.; Li, Z.; Jin, L.; Wang, Z.; Deng, Y.; He, N. Improvement on controllable fabrication of streptavidin-modified three-layer core-shell $\mathrm{Fe}_{3} \mathrm{O}_{4} @ \mathrm{SiO}_{2} @ \mathrm{Au}$ magnetic nanocomposites with low fluorescence background. J. Biomed. Nanotechnol. 2013, 9, 674-684. [CrossRef] [PubMed]

71. Greasley, S.L.; Page, S.J.; Sirovica, S.; Chen, S.; Martin, R.A.; Riveiro, A.; Hanna, J.V.; Porter, A.E.; Jones, J.R. Controlling particle size in the Stöber process and incorporation of calcium. J. Colloid Interfaces Sci. 2016, 469, 213-223. [CrossRef] [PubMed]

72. Petri-Fink, A.; Hofmann, H. Superparamagnetic Iron Oxide Nanoparticles (SPIONs): From Synthesis to In Vivo Studies-A Summary of the Synthesis, Characterization, In Vitro, and In Vivo Investigations of SPIONs With Particular Focus on Surface and Colloidal Properties. IEEE Trans. NanoBiosci. 2007, 6, 289-297. [CrossRef]

73. Priyadarshana, G.; Kottegoda, N.; Senaratne, A.; de Alwis, A.; Karunaratne, V. Synthesis of Magnetite Nanoparticles by Top-Down Approach from a High Purity Ore. J. Nanomater. 2015, 2015, 317. [CrossRef]

74. Zeynizadeh, B.; Gilanizadeh, M. Green and highly efficient approach for the reductive coupling of nitroarenes to azoxyarenes using the new mesoporous $\mathrm{Fe}_{3} \mathrm{O}_{4} @ \mathrm{SiO}_{2} @ \mathrm{Co}-\mathrm{Zr}-\mathrm{Sb}$ catalyst. Res. Chem. Intermed. 2020, 46, 2969-2984. [CrossRef]

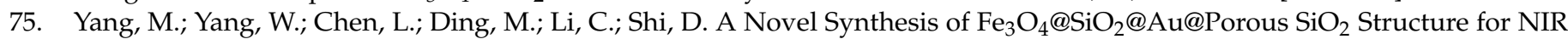
Irradiation-Induced DOX Release and Cancer Treatment. Dose Response 2020, 18, 1-8. [CrossRef]

76. Lima, M.; Macuvele, D.; Muller, L.; Nones, J.; Silva, L.; Fiori, M.; Soares, C.; Riella, H. Synthesis and Potential Adsorption of $\mathrm{Fe}_{3} \mathrm{O}_{4} @ \mathrm{C}$ Core-Shell Nanoparticles for to Removal of Pollutants in Aqueous Solutions: A Brief Review. J. Adv. Chem. Eng. 2017, 7, 1-11.

77. Ghosh Chaudhuri, R.; Paria, S. Core/Shell Nanoparticles: Classes, Properties, Synthesis Mechanisms, Characterization, and Applications. Chem. Rev. 2012, 112, 2373-2433. [CrossRef] [PubMed]

78. Cunningham, A.; Bürgi, T. Bottom-up Organisation of Metallic Nanoparticles. In Nano-Optics and Nanophotonics-Amorphous Nano Photonics; Rockstuhl, C., Scharf, T., Eds.; Springer: Berlin/Heidelberg, Germany, 2013; pp. 1-37. 
79. Kumar, S.; Bhushan, P.; Bhattacharya, S. Fabrication of Nanostructures with Bottom-up Approach and Their Utility in Diagnostics, Therapeutics, and Others. In Environmental, Chemical and Medical Sensors; Bhattacharya, S., Ed.; Springer: Berlin/Heidelberg, Germany, 2018; pp. 167-198.

80. Escudero, A.; Carrillo-Carrión, C.; Romero-Ben, E.; Franco, A.; Rosales-Barrios, C.; Castillejos, M.C.; Khiar, N. Molecular Bottom-Up Approaches for the Synthesis of Inorganic and Hybrid Nanostructures. Inorganics 2021, 9, 58. [CrossRef]

81. Zhao, X.; Wei, C.; Gai, Z.; Yu, S.; Ren, X. Chemical vapor deposition and its application in surface modification of nanoparticles. Chem. Papers 2019, 74,767-778. [CrossRef]

82. De Filpo, G.; Pantuso, E.; Armentano, K.; Formoso, P.; di Profio, G.; Poerio, T.; Fontananova, E.; Meringolo, C.; Mashin, A.I.; Nicoletta, F.P. Chemical Vapor Deposition of Photocatalyst Nanoparticles on PVDF Membranes for Advanced Oxidation Processes. Membranes 2018, 8, 35. [CrossRef] [PubMed]

83. Sudheer, K.G.; Rao, J.V.R. Thin film deposition, formation of nanoparticles and variation of resistance of deposited sample with temperature. Int. J. Nanotechnol. 2013, 3, 1-10.

84. Markelonis, A.R.; Wang, J.S.; Ullrich, B.; Wai, C.M.; Brown, G.J. Nanoparticle film deposition using a simple and fast centrifuge sedimentation method. Appl. Nanosci. 2014, 5, 457-468. [CrossRef]

85. Majidi, S.; Sehrig, F.Z.; Farkhani, S.M.; Goloujeh, M.S.; Akbarzadeh, A. Current methods for synthesis of magnetic nanoparticles. Artif. Cells Nanomed. Biotechnol. 2016, 44, 722-734. [CrossRef]

86. Reau, A.; Guizard, B.; Mengeot, C.; Boulanger, L.; Ténégal, F. Large Scale Production of Nanoparticles by Laser Pyrolysis. Mater. Sci. Forum 2007, 534-536, 85-88. [CrossRef]

87. Sneh, O.; Clark-Phelps, B.; Londergan, A.R.; Winkler, J.; Seidel, T.E. Thin Film Atomic Layer Deposition Equipment for Semiconductor Processing. Thin Solid Film. 2002, 402, 248-261. [CrossRef]

88. Rivera-Chaverra, M.J.; Restrepo-Parra, E.; Acosta-Medina, C.D.; Mello, A.; Ospina, R. Synthesis of Oxide Iron Nanoparticles Using Laser Ablation for Possible Hyperthermia Applications. Nanomaterials 2020, 10, 2099. [CrossRef]

89. Sadrolhosseini, A.; Mahdi, M.A.; Alizadeh, F.; Rashid, S.A. Laser Ablation Technique for Synthesis of Metal Nanoparticle in Liquid. In Laser Technology and Its Applications; Ma, Y., Ed.; IntechOpen: London, UK, 2018; pp. 63-83.

90. Kumar, P.; Kumar, R.; Kanjilal, D.; Knobel, M.; Thakur, P.; Chae, K.H. Ion beam synthesis of Ni nanoparticles embedded in quartz. J. Vac. Science Technol. B 2008, 26, L36-L40. [CrossRef]

91. Wang, W.; Luo, J.; Fan, Q.; Suzuki, M.; Suzuki, I.S.; Engelhard, M.H.; Lin, Y.; Kim, N.; Wang, J.Q.; Zhong, C.-J. Monodispersed Core-Shell $\mathrm{Fe}_{3} \mathrm{O}_{4} @ \mathrm{Au}$ Nanoparticles. J. Phys. Chem. B 2005, 109, 21593-21601. [CrossRef] [PubMed]

92. Phadtare, S.; Kumar, A.; Vinod, V.P.; Dash, C.; Palaskar, D.V.; Rao, M.; Shukla, P.G.; Sivaram, S.; Sastry, M. Direct Assembly of Gold Nanoparticle "Shells" on Polyurethane Microsphere "Cores" and Their Application as Enzyme Immobilization Templates. Chem. Mater. 2003, 15, 1944-1949. [CrossRef]

93. Wang, X.; Yang, T.; Jiao, K. Electrochemical sensing the DNA damage in situ induced by a cathodic process based on Fe@Fe $\mathrm{O}_{3}$ core-shell nanonecklace and Au nanoparticles mimicking metal toxicity pathways in vivo. Biosens. Bioelectron. 2009, 25, 668-673. [CrossRef]

94. Kim, H.; Achermann, M.; Balet, L.P.; Hollingsworth, J.A.; Klimov, V.I. Synthesis and characterization of CoCdSe core-shell nanocomposites-Bifunctional magetic-optical nanocrystals. J. Am. Chem. Soc. 2005, 127, 544-546. [PubMed]

95. Caruso, F. Nanoengineering of Particle Surfaces. Adv. Mater. 2001, 13, 11-22. [CrossRef]

96. Oyama, H.Y.; Sprycha, R.; Xie, Y.; Partch, R.E.; Matijevic, E. Coating of uniform inorganic particles with polymers. J. Colloid Interfaces Sci. 1993, 160, 298-303. [CrossRef]

97. Gates, B.D.; Xu, Q.; Stewart, M.; Ryan, D.; Willson, C.G.; Whitesides, G.M. New Approaches to Nanofabrication Molding, Printing, and Other Techniques. Chem. Rev. 2005, 105, 1171-1196. [CrossRef]

98. Aryal, S.; Park, H.; Leary, J.F.; Key, J. Top-down fabrication-based nano/microparticles for molecular imaging and drug delivery. Int. J. Nanomed. 2019, 14, 6631-6644. [CrossRef]

99. Merkel, T.J.; Herlihy, K.P.; Nunes, J.; Orgel, R.M.; Rolland, J.P.; DeSimone, J.M. Scalable, shape-specific, top-down fabrication methods for the synthesis of engineered colloidal particles. Langmuir 2010, 26, 13086-13096. [CrossRef] [PubMed]

100. Sadighian, S.; Rostamizadeh, K.; Hosseini-Monfared, H.; Hamidi, M. Doxorubicin-conjugated core-shell magnetite nanoparticles as dual-targeting carriers for anticancer drug delivery. Colloids Surf. B Biointerfaces 2014, 117, 406-413. [CrossRef] [PubMed]

101. Semkina, A.; Abakumov, M.; Grinenko, N.; Abakumov, A.; Skorikov, A.; Mironova, E.; Davydova, G.; Majouga, A.G.; Nukolova, N.; Kabanov, A.; et al. Core-shell-corona doxorubicin-loaded superparamagnetic $\mathrm{Fe}_{3} \mathrm{O}_{4}$ nanoparticles for cancer theranostics. Colloids Surf. B Biointerfaces 2015, 136, 1073-1080. [CrossRef] [PubMed]

102. Zhang, J.; Zhai, S.; Li, S.; Xiao, Z.; Song, Y.; An, Q.; Tian, G. Pb(II) removal of $\mathrm{Fe}_{3} \mathrm{O}_{4} @ \mathrm{SiO}_{2}-\mathrm{NH}_{2}$ core-shell nanomaterials prepared via a controllable sol-gel process. Chem. Eng. J. 2013, 215-216, 461-471. [CrossRef]

103. Ghosh, S.; Badruddoza, A.Z.; Uddin, M.S.; Hidajat, K. Adsorption of chiral aromatic amino acids onto carboxymethyl- $\beta$ cyclodextrin bonded $\mathrm{Fe}_{3} \mathrm{O}_{4} / \mathrm{SiO}_{2}$ core-shell nanoparticles. J. Colloid Interfaces Sci. 2011, 354, 483-492. [CrossRef]

104. He, X.; Liu, F.; Liu, L.; Duan, T.; Zhang, H.; Wang, Z. Lectin-Conjugated $\mathrm{Fe}_{2} \mathrm{O}_{3} @ \mathrm{Au}$ Core@Shell Nanoparticles as Dual Mode Contrast Agents for In Vivo Detection of Tumor. Mol. Pharmaceut. 2014, 11, 738-745. [CrossRef]

105. Madrid, S.I.U.; Pal, U.; Kang, Y.S.; Kim, J.; Kwon, H.; Kim, J. Fabrication of $\mathrm{Fe}_{3} \mathrm{O}_{4} @ \mathrm{mSiO}_{2}$ Core-Shell Composite Nanoparticles for Drug Delivery Applications. Nanoscale Res. Lett. 2015, 10, 1-8. 
106. Wang, J.; Zheng, S.; Shao, Y.; Liu, J.; Xu, Z.; Zhu, D. Amino-functionalized $\mathrm{Fe}_{3} \mathrm{O}_{4} @ \mathrm{SiO}_{2}$ core-shell magnetic nanomaterial as a novel adsorbent for aqueous heavy metals removal. J. Colloid Interfaces Sci. 2010, 349, 293-299. [CrossRef]

107. Andhariya, N.; Chudasama, B.; Mehta, R.V.; Upadhyay, R.V. Nanoengineering of methylene blue loaded silica encapsulated magnetite nanospheres and nanocapsules for photodynamic therapy. J. Nanopart. Res. 2011, 13, 3619-3631. [CrossRef]

108. Faaliyan, K.; Abdoos, H.; Borhani, E.; Afghahi, S.S.S. Magnetite-silica nanoparticles with core-shell structure: Single-step synthesis, characterization and magnetic behavior. J. Sol Gel Sci. Technol. 2018, 88, 609-617. [CrossRef]

109. Shariati, S.; Chinevari, A.; Ghorbani, M. Simultaneous Removal of Four Dye Pollutants in Mixture Using Amine Functionalized Kit-6 Silica Mesoporous Magnetic Nanocomposite. Silicon 2019, 12, 1865-1878. [CrossRef]

110. Fessi, H.; Puisieux, F.; Devissaguet, J.P.; Ammoury, N.; Benita, S. Nanocapsule formation by interfacial polymer deposition following solvent displacement. Int. J. Pharm. 1989, 55, 1-4. [CrossRef]

111. Meizhen, G.; Wen, L.; Jingwei, D.; Zhirong, Z.; Bingjun, Y. Synthesis and Characterization of Superparamagnetic $\mathrm{Fe}_{3} \mathrm{O}_{4} @ \mathrm{SiO}_{2}$ Core-Shell Composite Nanoparticles. World J. Condens. Matter Phys. 2011, 1, 49-54.

112. Lu, Y.; Yin, Y.; Mayers, B.T.; Younan, X. Modifying the surface properties of superparamagnetic iron oxide nanoparticles through a sol-gel approach. Nano Lett. 2002, 2, 183-186. [CrossRef]

113. Wu, W.; He, Q.; Jiang, C. Magnetic iron oxide nanoparticles: Synthesis and surface functionalization strategies. Nanoscale Res. Lett. 2008, 3, 397-415. [CrossRef] [PubMed]

114. Morel, A.L.; Nikitenko, S.I.; Gionnet, K.; Wattiaux, A.; Lai-Kee-Him, J.; Labrugere, C.; Chevalier, B.; Deleris, G.; Petibois, C.; Brisson, A.; et al. Sonochemical Approach to the Synthesis of $\mathrm{Fe}_{3} \mathrm{O}_{4} @ \mathrm{SiO}_{2}$ Core-Shell Nanoparticles with Tunable Properties. ACS Nano 2008, 2, 847-856. [CrossRef]

115. Sonmez, M.; Georgescu, M.; Alexandrescu, L.; Gurau, D.; Ficai, A.; Ficai, D.; Andronescu, E. Synthesis and Applications of $\mathrm{Fe}_{3} \mathrm{O}_{4} / \mathrm{SiO}_{2}$ Core-Shell Materials. Curr. Pharm. Design 2015, 21, 1-12. [CrossRef]

116. Chang, Q.; Zhu, L.; Yu, C.; Tang, H. Synthesis and properties of magnetic and luminescent $\mathrm{Fe}_{3} \mathrm{O}_{4} / \mathrm{SiO} \mathrm{O}_{2} / \mathrm{Dye} / \mathrm{SiO}{ }_{2}$ nanoparticles. J. Lumin. 2008, 128, 1890-1895. [CrossRef]

117. Ardelean, I.L.; Ficai, D.; Sonmez, M.; Oprea, O.; Nechifor, G.; Andronescu, E.; Ficai, A.; Titu, M.A. Hybrid Magnetic Nanostructures for Cancer Diagnosis and Therapy. Anticancer Agents Med. Chem. 2019, 19, 6-16. [CrossRef]

118. Radulescu, M.; Popescu, S.; Ficai, D.; Sonmez, M.; Oprea, O.; Spoiala, A.; Ficai, A.; Andronescu, E. Advances in Drug Delivery Systems, from 0 to 3D superstructures. Curr. Drug Targets 2018, 19, 393-405. [CrossRef]

119. Pang, S.C.; Kho, S.Y.; Chin, S.F. Fabrication of Magnetite/Silica/Titania Core-Shell Nanoparticles. J. Nanomater. 2012, $2012,1-6$. [CrossRef]

120. Cheng, J.P.; Ma, R.; Li, M.; Wu, J.S.; Liu, F.; Zhang, X.B. Anatase nanocrystals coating on silica-coated magnetite: Role of polyacrylic acid treatment and its photocatalytic properties. Chem. Eng. J. 2012, 210, 80-86. [CrossRef]

121. Wang, S.; Tang, J.; Zhao, H.; Wan, J.; Chen, K. Synthesis of magnetite-silica core-shell nanoparticles via direct silicon oxidation. J. Colloid Interface Sci. 2014, 432, 43-46. [CrossRef]

122. Barnakov, Y.A.; Yu, M.H.; Rosenzweig, Z. Manipulation of the Magnetic Properties of Magnetite-Silica Nanocomposite Materials by ControlledStober Synthesis. Langmuir 2005, 21, 7524-7527. [CrossRef] [PubMed]

123. Patron, L.; Marinescu, G.; Culita, D.; Diamandescu, L.; Carp, O. Thermal stability of amino acid-(tyrosine and tryptophan) coated magnetites. J. Ther. Anal. Calorim. 2008, 91, 627-632. [CrossRef]

124. Marinescu, G.; Patron, L.; Culita, D.C.; Neagoe, C.; Lepadatu, C.I.; Balint, I.; Bessais, L.; Cizmas, C.B. Synthesis of magnetite nanoparticles in the presence of aminoacids. J. Nanopart. Res. 2006, 8, 1045-1051. [CrossRef]

125. Carp, O.; Patron, L.; Culita, D.C.; Budrugeac, P.; Feder, M.; Diamandescu, L. Thermal analysis of two types of dextran-coated magnetite. J. Ther. Anal. Calorim. 2010, 101, 181-187. [CrossRef]

126. Sönmez, M.; Ficai, D.; Ficai, A.; Alexandrescu, L.; Georgescu, M.; Trusca, R.; Gurau, D.; Titu, M.A.; Andronescu, E. Applications of mesoporous silica in biosensing and controlled release of insulin. Int. J. Pharm. 2018, 549, 179-200. [CrossRef] [PubMed]

127. Gonzalez, C.C.; Pérez, C.A.M.; Martínez, A.M.; Armendáriz, I.O.; Tapia, O.Z.; Martel-Estrada, A.; García-Casillas, P.E. Development of Antibody-Coated Magnetite Nanoparticles for Biomarker Immobilization. J. Nanomater. 2014, 2014, 1-7. [CrossRef]

128. Ibrahim, A.S.S.; Al-Salamah, A.A.; El-Toni, A.M.; El-Tayeb, M.A.; Elbadawi, Y.B. Immobilization of cyclodextrin glucanotransferase on aminopropyl-functionalized silica-coated superparamagnetic nanoparticles. Electron. J. Biotechnol. 2013, 16, 1-17. [CrossRef]

129. Maurizi, L.; Claveau, A.; Hofmann, H. Polymer Adsorption on Iron Oxide Nanoparticles for One-Step Amino-Functionalized Silica Encapsulation. J. Nanomater. 2015, 2015, 1-6. [CrossRef]

130. Noma, S.A.A.; Ulu, A.; Koytepe, S.; Ateş, B. Preparation and characterization of amino and carboxyl functionalized core-shell $\mathrm{Fe}_{3} \mathrm{O}_{4} / \mathrm{SiO}_{2}$ for L-asparaginase immobilization: A comparison study. Biocatal. Biotransform. 2020, 38, 392-404. [CrossRef]

131. Mirzaee, M.; Kakaei, S.; Khanchi, A. Preparation and characterization of $\mathrm{Fe}_{3} \mathrm{O}_{4}-\mathrm{SiO}_{2}-\mathrm{APTES}$ core-shell nanoparticles. In Proceedings of the 4th International Conference on Nanostructures, Kish Island, Iran, 12-14 March 2012; pp. 1-3.

132. Zhang, Z.; Chai, A. Core-shell magnetite-silica composite nanoparticles enhancing DNA damage induced by a photoactive platinum-diimine complex in red light. J. Inorg. Biochem. 2012, 117, 71-76. [CrossRef]

133. Liu, X.; Ma, Z.; Xing, J.; Liu, H. Preparation and characterization of amino-silane modified superparamagnetic silica nanospheres. J. Magn. Magn. Mater. 2004, 270, 1-6. [CrossRef] 
134. Dougherty, T. Photosensitizers: Therapy and detection of malignant tumors. Photochem. Photobiol. 1987, 45, 879-889. [CrossRef] [PubMed]

135. Huang, Z. A review of progress in clinical photodynamic therapy. Technol. Cancer Res. Treat. 2005, 4, 283-293. [CrossRef]

136. Fahmy, S.A.; Azzazy, H.M.E.; Schaefer, J. Liposome Photosensitizer Formulations for Effective Cancer Photodynamic Therapy. Pharmaceutics 2021, 13, 1345. [CrossRef] [PubMed]

137. Campbell, J.L.; Arora, J.; Cowell, S.F.; Garg, A.; Eu, P.; Bhargava, S.K.; Bansal, V. Quasi-Cubic Magnetite/Silica Core-Shell Nanoparticles as Enhanced MRI Contrast Agents for Cancer Imaging. PLoS ONE 2011, 6, e21857. [CrossRef] [PubMed]

138. Xiao, Y.; Du, J. Superparamagnetic nanoparticles for biomedical applications. J. Mater. Chem. B 2020, 8, 354-367. [CrossRef] [PubMed]

139. Ficai, D.; Iliev, A.; Ficai, A.; Trușcă, V.G.; Gafencu, A.V.; Bucătariu, S.-M.; Fundeanu-Constantin, G.; Simionescu, M.; Andronescu, E. Polymer Vesicles and Tubes and Related Technology of Manufacturing. National Patent No. A 01054/05.12.2018, 5 December 2018.

140. Philippova, O.; Barabanova, A.; Molchanov, V.; Khokhlov, A. Magnetic polymer beads: Recent trends and developments in synthetic design and applications. Eur. Polym. J. 2011, 47, 542-559. [CrossRef]

141. Yipel, M.; Ghica, M.; Kaya, M.; Spoiala, A.; Radulescu, M.; Ficai, D.; Ficai, A.; Bleotu, C.; Cornelia, N. Multifunctional Materials for Cancer Therapy: From Antitumoral Agents to Innovative Administration. Curr. Org. Chem. 2016, 20, 2934-2948. [CrossRef]

142. Popescu, S.; Ardelean, I.L.; Gudovan, D.; Rădulescu, M.; Ficai, D.; Ficai, A.; Vasile, B.Ş.; Andronescu, E. Multifunctional materials such as $\mathrm{MCM}-41 \div \mathrm{Fe}_{3} \mathrm{O}_{4} \div$ folic acid as drug delivery system. Rom. J. Morphol. Embryol. 2016, 57, 483-489.

143. Ibrahim, A.S.S.; Al-Salamah, A.A.; El-Toni, A.M.; El-Tayeb, M.A.; Elbadawi, Y.B. Cyclodextrin glucanotransferase immobilization onto functionalized magnetic double mesoporous core-shell silica nanospheres. Electron. J. Biotechnol. 2014, 17, 55-64. [CrossRef]

144. Hu, F.; Zhang, H.; Lin, H.; Deng, C.; Zhang, X. Enzyme inhibitor screening by electrospray mass spectrometry with immobilized enzyme on magnetic silica microspheres. J. Am. Soc. Mass Spectrom. 2008, 19, 865-873. [CrossRef] [PubMed]

145. Mamani, J.B.; Gamarra, L.F.; Brito, G.E.d.S. Synthesis and characterization of $\mathrm{Fe}_{3} \mathrm{O}_{4}$ nanoparticles with perspectives in biomedical applications. Mater. Res. 2014, 17, 542-549. [CrossRef]

146. Azcona, P.; Zysler, R.; Lassalle, V. Simple and novel strategies to achieve shape and size control of magnetite nanoparticles intended for biomedical applications. Colloids Surf. A 2016, 504, 320-330. [CrossRef]

147. Daoush, W. Co-Precipitation and Magnetic Properties of Magnetite Nanoparticles for Potential Biomedical Applications. J. Nanomed. Res. 2017, 5, 1-6. [CrossRef]

148. Yew, Y.P.; Shameli, K.; Miyake, M.; Khairudin, N.B.B.A.; Mohamad, S.E.B.; Naiki, T.; Lee, K.X. Green biosynthesis of superparamagnetic magnetite $\mathrm{Fe}_{3} \mathrm{O}_{4}$ nanoparticles and biomedical applications in targeted anticancer drug delivery system: A review. Arab. J. Chem. 2020, 13, 2287-2308. [CrossRef] 